\title{
The HadGEM2 family of Met Office Unified Model climate configurations
}

The HadGEM2 Development Team: G. M. Martin ${ }^{1}$, N. Bellouin ${ }^{1}$, W. J. Collins ${ }^{1}$, I. D. Culverwell ${ }^{1}$, P. R. Halloran ${ }^{1}$, S. C. Hardiman ${ }^{1}$, T. J. Hinton ${ }^{1}$, C. D. Jones ${ }^{1}$, R. E. McDonald ${ }^{1}$, A. J. McLaren ${ }^{1}$, F. M. O'Connor ${ }^{1}$, M. J. Roberts ${ }^{1}$, J. M. Rodriguez ${ }^{1}$, S. Woodward ${ }^{1}$, M. J. Best ${ }^{1}$, M. E. Brooks ${ }^{1}$, A. R. Brown ${ }^{1}$, N. Butchart ${ }^{1}$, C. Dearden ${ }^{2}$, S. H. Derbyshire ${ }^{1}$, I. Dharssi ${ }^{3}$, M. Doutriaux-Boucher ${ }^{1}$, J. M. Edwards ${ }^{1}$, P. D. Falloon ${ }^{1}$, N. Gedney ${ }^{1}$, L. J. Gray ${ }^{4}$, H. T. Hewitt ${ }^{1}$, M. Hobson ${ }^{1}$, M. R. Huddleston ${ }^{1}$, J. Hughes ${ }^{1}$, S. Ineson ${ }^{1}$, W. J. Ingram ${ }^{1,4}$, P. M. James ${ }^{5}$, T. C. Johns ${ }^{1}$, C. E. Johnson ${ }^{1}$, A. Jones ${ }^{1}$, C. P. Jones ${ }^{1}$, M. M. Joshi ${ }^{6}$, A. B. Keen ${ }^{1}$, S. Liddicoat ${ }^{1}$, A. P. Lock ${ }^{1}$, A. V. Maidens ${ }^{1}$, J. C. Manners ${ }^{1}$, S. F. Milton ${ }^{1}$, J. G. L. Rae ${ }^{1}$, J. K. Ridley ${ }^{1}$, A. Sellar ${ }^{1}$, C. A. Senior ${ }^{1}$, I. J. Totterdell ${ }^{1}$, A. Verhoef ${ }^{7}$, P. L. Vidale $^{6}$, and A. Wiltshire ${ }^{1}$

${ }^{1}$ Met Office, FitzRoy Road, Exeter, UK

${ }^{2}$ School of Earth, Atmospheric and Environmental Sciences, University of Manchester, Manchester, UK

${ }^{3}$ Centre for Australian Weather and Climate, Bureau of Meteorology, Melbourne, Australia

${ }^{4}$ Department of Atmospheric, Oceanic and Planetary Physics, Clarendon Laboratory, Oxford University, Parks Road, Oxford, UK

${ }^{5}$ Deutscher Wetterdienst, Offenbach, Germany

${ }^{6}$ National Centre for Atmospheric Science, Climate Directorate, Dept Of Meteorology, University of Reading, Earley Gate, Reading, UK

${ }^{7}$ Soil Research Centre, Department of Geography and Environmental Science, University of Reading, Whiteknights Reading, UK

Received: 21 February 2011 - Published in Geosci. Model Dev. Discuss.: 1 April 2011

Revised: 27 July 2011 - Accepted: 1 August 2011 - Published: 7 September 2011

\begin{abstract}
We describe the HadGEM2 family of climate configurations of the Met Office Unified Model, MetUM. The concept of a model "family" comprises a range of specific model configurations incorporating different levels of complexity but with a common physical framework. The HadGEM2 family of configurations includes atmosphere and ocean components, with and without a vertical extension to include a well-resolved stratosphere, and an Earth-System (ES) component which includes dynamic vegetation, ocean biology and atmospheric chemistry. The HadGEM2 physical model includes improvements designed to address specific systematic errors encountered in the previous climate configuration, HadGEM1, namely Northern Hemisphere continental temperature biases and tropical sea surface temperature biases and poor variability. Targeting these biases was crucial in order that the ES configuration could represent important biogeochemical climate feedbacks. Detailed descriptions and evaluations of particular HadGEM2 family mem-
\end{abstract}

Correspondence to: G. M. Martin (gill.martin@metoffice.gov.uk) bers are included in a number of other publications, and the discussion here is limited to a summary of the overall performance using a set of model metrics which compare the way in which the various configurations simulate present-day climate and its variability.

\section{Introduction}

Useful climate projections depend on having the most comprehensive and accurate models of the climate system. However, any single model will still have limitations in its application for certain scientific questions and it is increasingly apparent that we need a range of models to address the variety of applications. There are two primary reasons for this. First, there is inherent uncertainty in projections, which means that ensemble frameworks are needed with many model integrations. Second, technological advances have not kept pace with scientific advances. A model that included the latest understanding of the science at the highest resolution would require computers of several orders of

Published by Copernicus Publications on behalf of the European Geosciences Union. 
magnitude faster than today's machines. For these reasons, the Met Office Hadley Centre has adopted a flexible approach to climate modelling based on model "families" within which we define a suite of models aimed at addressing different aspects of the climate projection problem. All of these models are configurations of the Met Office's unified weather forecasting and climate modelling system, MetUM, which has been developed using a software engineering approach that accounts for the diverse requirements of climate and weather applications (Easterbrook and Johns, 2009).

The members of such a model family may differ in a number of ways: resolution, vertical extent, region (e.g. limited area or global), complexity (e.g. atmosphere-only, coupled atmosphere-ocean, inclusion of earth system feedbacks). In principle, changes to parameter settings in the model may be required in order to accommodate different resolutions if, for example, a process has a clear theoretical resolution dependence or if increases in resolution allow previously parametrised processes to be explicitly resolved. However, in practice, few such changes are required. Ultimately, it is crucial that the basic physical configuration of the model family is consistent between family members and that any changes made are limited to those required for the different functionality. Such restrictions allow significant benefits in terms of addressing key scientific questions using the appropriate model while remaining consistent with other modelling studies and/or climate projections made with other family members.

The HadGEM2 family of model configurations includes atmosphere, ocean and sea-ice components, with and without a vertical extension in the atmosphere model to include a well-resolved stratosphere, and Earth System components including the terrestrial and oceanic carbon cycle and atmospheric chemistry. The HadGEM2 physical model includes improvements designed to address specific systematic errors encountered in the previous climate configuration, HadGEM1, namely Northern Hemisphere continental temperature biases and tropical sea surface temperature biases and poor variability. Targeting these biases was crucial in order that the Earth System configuration could represent important biogeochemical climate feedbacks.

The paper is arranged as follows: the motivation for and development of the HadGEM2 family are described in Sect. 2, and the main changes made to the physical models between HadGEM1 and HadGEM2 are detailed in Sect. 3. Section 4 includes a detailed description of the configurations created so far using the family of components, along with a brief overall evaluation of performance, with reference to other published work in which additional detail can be found.

\section{Development of the HadGEM2 family}

Cox et al. (2000) showed that including the carbon cycle in climate models could dramatically change the predicted response of the HadCM3 model to anthropogenic forcing, from $4.0 \mathrm{~K}$ to $5.5 \mathrm{~K}$ by the year 2100 . A subsequent multi-model study has shown large uncertainty in the magnitude of this feedback (Friedlingstein et al., 2006). These studies highlight the importance of Earth System feedbacks in the climate system and the necessity of including such feedbacks in climate models in order to predict future climate change. Therefore, a key science question for this model family was the quantification of Earth System feedbacks and understanding the uncertainty associated with Earth System processes. Much of the work done to improve the atmosphere and ocean components of this model focussed on addressing systematic errors in HadGEM1 (Martin et al., 2006; Johns et al., 2006) that would otherwise lead to unrealistic simulation of the Earth-system feedbacks (e.g. regional errors in land surface temperature and humidity that would have lead to biases in modelled vegetation and unrealistic representation of the carbon cycle).

There was also a focus on other outstanding errors such as El Niño Southern Oscillation (ENSO) and tropical climate, which are major weaknesses of HadGEM1 (Martin et al., 2010; Johns et al., 2006). HadGEM1 exhibits a marked cold bias in the equatorial Pacific, and Johns et al. (2006) showed that the observed eastward shift of the tropical convection during El Niño events, associated with a collapse of the Walker circulation, is not captured in this configuration. These errors are related to climatological trade winds that are too strong in the east Pacific, with the associated excessive zonal wind stress in the equatorial region driving excessive upwelling across much of the tropical Pacific.

Another area of interest was the representation of aerosols. Aerosol optical depths are underestimated globally in HadGEM1 compared with satellite observations and surface measurements (Collins et al., 2008) and the error in clear sky radiative fluxes is largely due to the lack of representation of natural (biogenic) continental aerosols and mineral dust aerosols in HadGEM1 (Bodas-Salcedo et al., 2008).

Finally, in order to investigate the role of the stratosphere in climate variability, there is a need to represent stratospheric ozone and dynamical processes. Improved representation of the stratosphere may prove important in identifying climate couplings, such as those driving variability in the North Atlantic Oscillation (NAO; Scaife et al., 2005).

The HadGEM2 model family comprises configurations made by combining model components which facilitate the representation of many different processes within the climate system, as illustrated in Fig. 1. These combinations have different levels of complexity for application to a wide range of science questions, although clearly many of the processes are interdependent. The shaded trapezoids illustrate the stages by which the full Earth System configuration can 


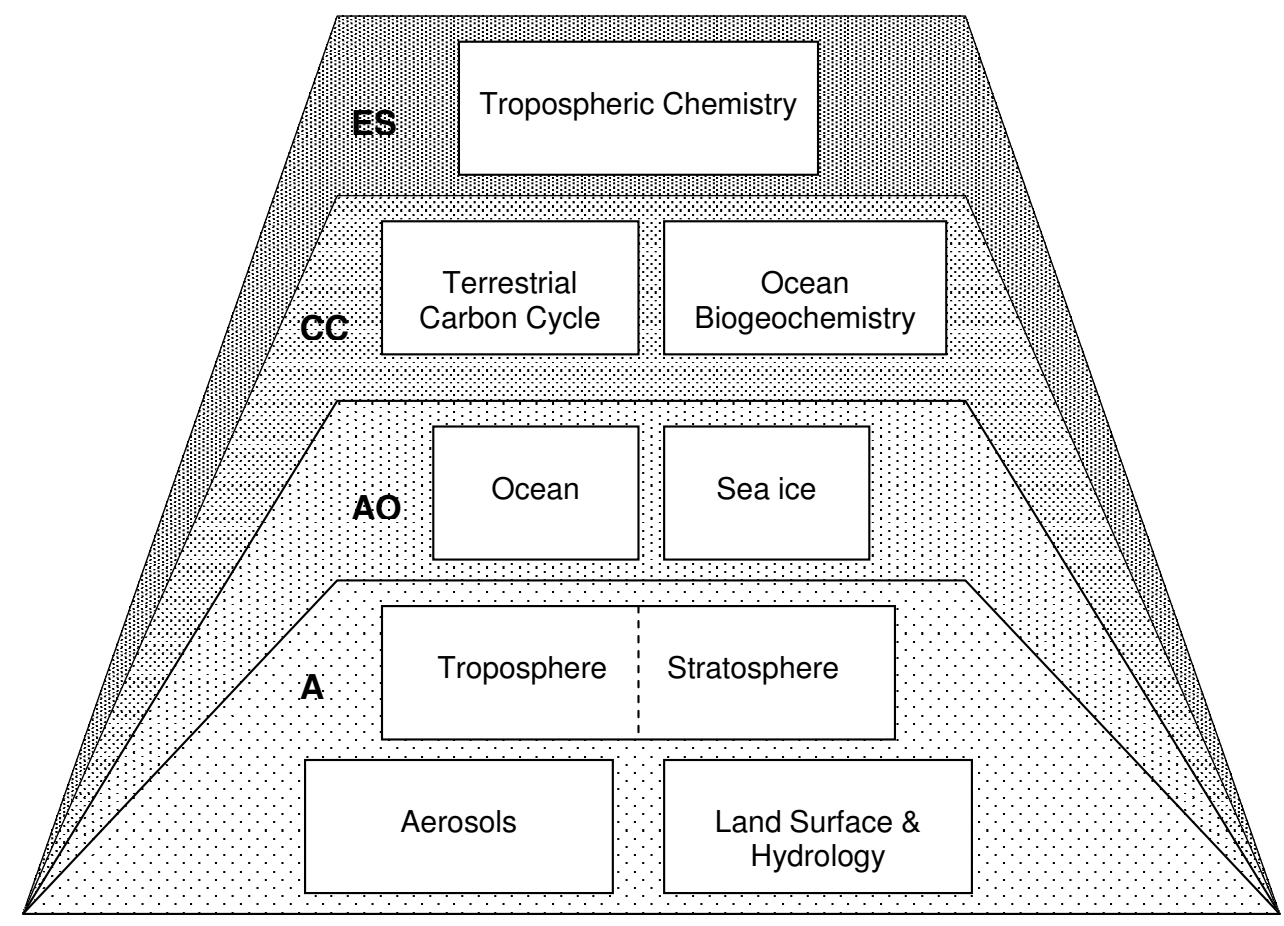

Fig. 1. Processes included in the HadGEM2 model family.

be built. Starting with the Atmosphere-only (A) configuration (with or without a well-resolved stratosphere, S), the addition of ocean and sea ice components constitute the coupled Atmosphere-Ocean (AO) configuration, to which the carbon cycle processes can be added to form the coupled Carbon Cycle (CC) configuration, and finally the addition of tropospheric chemistry completes the full Earth System (ES) configuration.

\section{Changes made between HadGEM1 and HadGEM2}

Details of, and references for, the changes made between HadGEM1 and HadGEM2, and the additional processes represented in the HadGEM2 model family (terrestrial and oceanic ecosystems and tropospheric chemistry), are given in Appendix A. The main changes are outlined below.

A seamless approach to reducing the relevant systematic errors in the atmosphere model was used, in which the errors were examined on a range of spatial and temporal scales within the MetUM. This work, detailed in Martin et al. (2010), has resulted in several important changes to the model parametrisations. The most significant changes in terms of the systematic biases are the implementation of an adaptive detrainment parametrisation in the convection scheme, which improves the simulation of tropical convection and leads to a much reduced (and more realistic) wind stress over the tropical Pacific, and a package of changes including an alteration to the treatment of excess water from super-saturated soil surfaces and improved representation of the lifetime of convective cloud, which together lead to reductions in the land surface warm bias over northern continents.

Several changes and additions to the representation of aerosol have been carried out. Improvements include changes to existing aerosol species, such as sulphate and biomass-burning aerosols, and representation of additional species, such as mineral dust, fossil-fuel organic carbon, and secondary organic aerosol from biogenic terpene emissions. Emission datasets for aerosol precursors and primary aerosols have also been revised, with the HadGEM2 family typically using datasets created in support of the fifth Climate Model Intercomparison Project (CMIP-5; more information online at http://www-pcmdi.llnl.gov/projects/cmip/ index.php) simulations (Lamarque et al., 2010). These changes improve the agreement in aerosol optical depth between model and observations, and allow the seasonal variations in aerosols over the Northern Hemisphere continental regions to be captured (Bellouin et al., 2007).

A 10-yr timescale drift in global sea surface temperatures (SSTs) was identified in HadGEM1, which is ameliorated by reducing the mixing in the upper ocean in HadGEM2. A change has been made (within the uncertainty range) to the background ocean vertical diffusivity profile in the thermocline, resulting in substantially reduced SST drift in the tropics and a reasonably balanced Top-Of the-Atmosphere (TOA) radiative flux $\left(\sim 0.5 \mathrm{Wm}^{-2}\right)$. Additional changes to 
Table 1. Current HadGEM2 configurations.

\begin{tabular}{ll}
\hline Configuration & Processes included \\
\hline HadGEM2-A & $\begin{array}{l}\text { Troposphere, Land Surface \& Hydrology, } \\
\text { Aerosols }\end{array}$ \\
\hline HadGEM2-O & Ocean and sea-ice \\
\hline HadGEM2-AO & $\begin{array}{l}\text { Troposphere, Land Surface \& Hydrology, } \\
\text { Aerosols, Ocean \& Sea-ice }\end{array}$ \\
\hline HadGEM2-CC & $\begin{array}{l}\text { Troposphere, Land Surface \& Hydrology, } \\
\text { Aerosols, Ocean \& Sea-ice, Terrestrial } \\
\text { Carbon Cycle, Ocean Biogeochemistry }\end{array}$ \\
\hline HadGEM2-CCS & $\begin{array}{l}\text { Troposphere, Land Surface \& Hydrology, } \\
\text { Aerosols, Ocean \& Sea-ice, Terrestrial } \\
\text { Carbon Cycle, Ocean Biogeochemistry, } \\
\text { Stratosphere }\end{array}$ \\
\hline HadGEM2-ES & $\begin{array}{l}\text { Troposphere, Land Surface \& Hydrology, } \\
\text { Aerosols, Ocean \& Sea-ice, Terrestrial } \\
\text { Carbon Cycle, Ocean Biogeochemistry, } \\
\text { Chemistry }\end{array}$ \\
\hline
\end{tabular}

the ocean include a reduction in the Laplacian viscosity at the equator which result in improved equatorial westward currents, and a change to the treatment of river outflow. The sea ice in HadGEM1 compared well with observations (McLaren et al., 2006), therefore only minor corrections and improvements were made to the sea ice component of HadGEM2.

The stratospheric component includes modifications to the radiation scheme and radiation spectral files appropriate for modelling the middle atmosphere. A source of water is introduced into the model that represents the water produced by methane oxidation in the stratosphere and mesosphere. There is also an additional physical parametrisation to describe the vertical transport and deposition of momentum by (sub gridscale) non-orographic gravity waves in addition to the existing orographic gravity wave scheme. Non-orographic gravity waves are known to play an important role in the dynamics of the mesosphere and tropical middle atmosphere.

New Earth System components include the terrestrial and oceanic ecosystems and tropospheric chemistry. The ecosystem components are introduced principally to allow simulation of the carbon cycle and its interactions with climate (Collins et al., 2011). The ocean biogeochemistry scheme also allows the feedback of dust fertilisation on oceanic carbon uptake. The tropospheric chemistry affects the radiative forcing through methane and ozone, and affects the rate at which sulphur dioxide emissions are converted to sulphate aerosol. In HadGEM2 the tropospheric chemistry is modelled interactively, allowing it to vary with meteorology and emissions.

\section{Evaluation of the HadGEM2 family}

\subsection{Current HadGEM2 configurations}

At the time of writing, several main HadGEM2 configurations have been created and evaluated (Table 1). Clearly this is not an exhaustive list of configurations which could form part of the HadGEM2 family; others could be created using different combinations of the process components shown in Fig. 1. Similarly, at the time of writing, the horizontal resolution used so far has been limited to that used in HadGEM1 (atmospheric horizontal resolution of $1.875^{\circ} \times 1.25^{\circ}$, which equates to about $140 \mathrm{~km}$ at mid-latitudes, and ocean horizontal resolution of $1.0^{\circ}$ longitude by $1.0^{\circ}$ latitude, with latitudinal resolution increasing smoothly from $30^{\circ} \mathrm{N} / \mathrm{S}$ to $0.33^{\circ}$ at equator).

The vertical resolution for atmosphere and ocean in most of the configurations in Table 1 also matches that used in HadGEM1 (Fig. 2, left panel). However, for the configuration in which the stratospheric component is included, a second vertical resolution for the atmosphere has been introduced which includes the vertical extension necessary to encompass the stratosphere and lower mesosphere (Fig. 2, right panel). Inclusion of the mesosphere is essential to simulate properly the wave-driving responsible for the stratospheric circulation. As well as an increased height of the model top, the vertically-extended configuration has more than double the vertical resolution within the stratosphere compared with the original configuration. Unfortunately, these changes not only increase the cost of the model by nearly doubling the vertical resolution, but the extended model also requires a shorter model timestep in order to ensure numerical stability. The overall cost of the vertically-extended model (around 2.5 times that of the 38 level configuration) is found to be prohibitive for long climate change runs incorporating both the stratosphere and the full Earth System (the latter itself triples the model cost compared with the AO configuration, half of which comes from the interactive chemistry and the rest from the ocean carbon cycle), so at the time of writing, only a coupled Carbon-Cycle configuration of the verticallyextended model (HadGEM2-CCS) has been built, in which ozone and methane concentrations are prescribed. In order to evaluate the impact of the vertically-extended model on the climate change projections, a parallel 38 level configuration (HadGEM2-CC) has also been created.

\subsection{Evaluation of model performance}

A number of measures giving a broad overview of model performance against present day climate observations or reanalyses, termed model metrics, now exist. Most of these measures are based on the composite mean square errors of a wide range of climate variables. The Climate Prediction Index (CPI, Murphy et al., 2004) was used extensively through the development of HadGEM2 to track the progress 

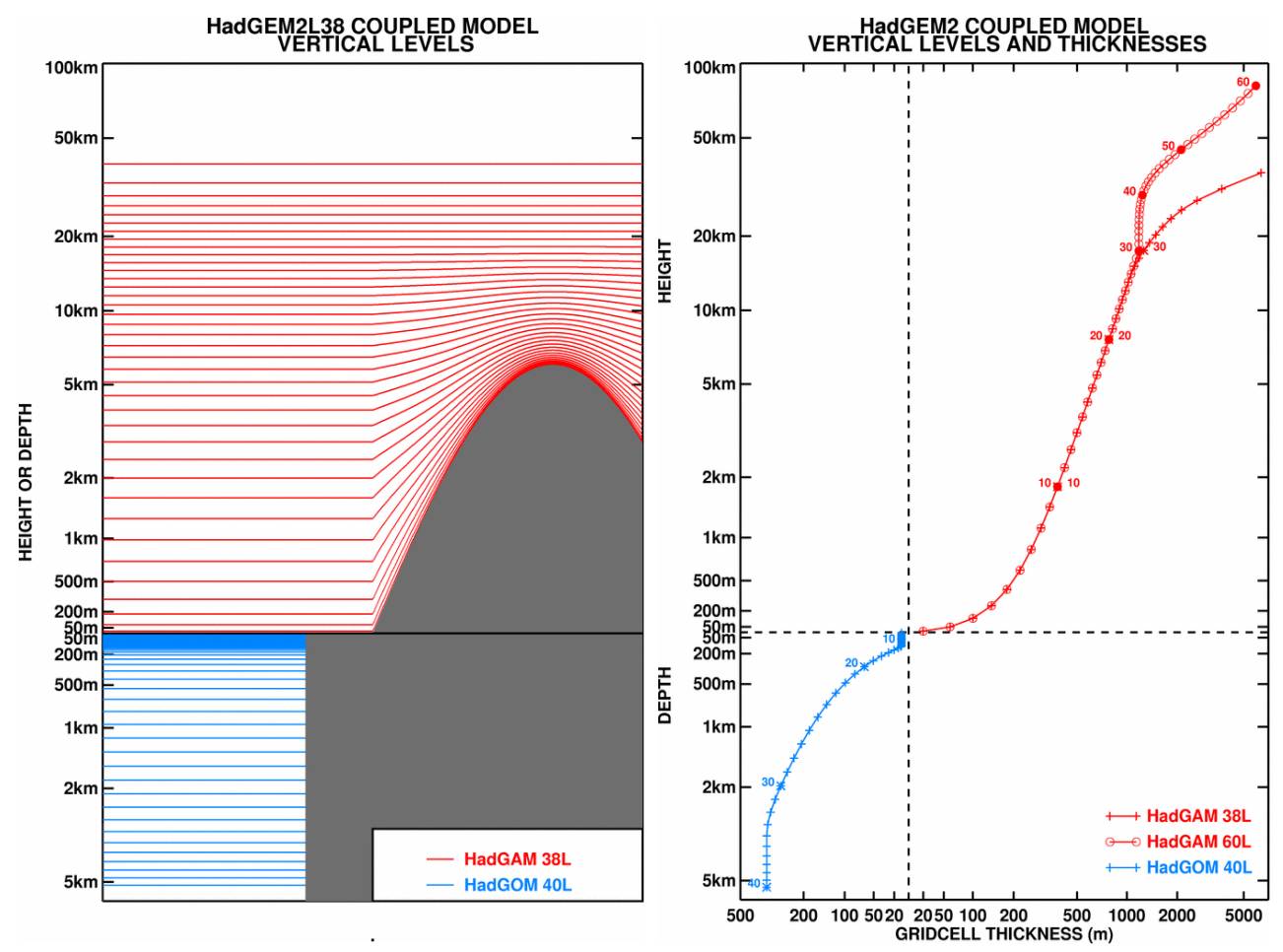

Fig. 2. Current vertical resolutions available. The vertical coordinate system in the atmosphere is height-based and terrain-following near the bottom boundary. Left: Schematic picture, showing impact of orography on atmosphere model levels. Right: Model level height (or depth) vs. thickness plotted for the $40 \mathrm{~L}$ ocean model configuration and the $38 \mathrm{~L}$ and $60 \mathrm{~L}$ atmosphere model configurations at a point with zero orography.

against HadGEM1. Martin et al. (2010) used the performance measure developed by Reichler and Kim (2008a, b) to evaluate the impact of the changes. This measure allows the performance in the Northern and Southern Hemisphere and the tropics to be evaluated, as well as the overall global performance. Using this index, Reichler and Kim (2008a) showed that HadGEM1 performed well in comparison with the other models participating in CMIP-3, with the exception of the tropical performance. Martin et al. (2010) subsequently showed a clear improvement in both tropical and Northern Hemisphere performance in HadGEM2-AO for the variables targeted during development.

In the following sections, we use a number of different metrics and methods to provide a broad overview of HadGEM2 performance. More detailed and process-based evaluations are undertaken in other publications describing aspects of the individual configurations, as referenced in the sections below. The model runs used in the following sections are generally either present-day (1980-2005) sections of historical coupled model runs, initialised in 1860 after spin-up of a pre-industrial control (the method of spin-up is described in Collins et al., 2011) and run through the 20th century, or atmosphere-only runs for the period 1979 to 2008 . Each of these methods uses forcing provided for CMIP5 for HadGEM2 experiments and CMIP3 for HadGEM1 experi- ments. Since a historical run of HadGEM2-AO was not available, a 100-yr present-day control run of this configuration was carried out using forcing relevant to the year 2000.

\subsubsection{Troposphere}

Standard metrics for the global troposphere are shown in the form of Taylor diagrams (Gates et al., 1999; Taylor, 2001), which compare the global distribution of multi-annual mean fields from models with corresponding multi-annual means from observations or reanalyses. Figure $3 \mathrm{a}-\mathrm{e}$ shows a range of fields including surface variables, radiation budget, thermodynamic and dynamical quantities on a range of pressure levels. Values from different observational datasets are compared alongside HadGEM2-ES in Fig. 3a, while results for the different family members are shown along with those from HadGEM1 (Martin et al., 2006) in Fig. 3b, c, d and e.

Comparison between the different reanalyses in Fig. $3 \mathrm{a}$ is revealing. There is good agreement for geopotential height, zonal winds and temperature, reasonable agreement for pressure at mean sea level (PMSL) and meridional winds but poor agreement for specific and relative humidity, both globally and regionally. ERA-40 suffered from known problems with humidity which were reduced in 

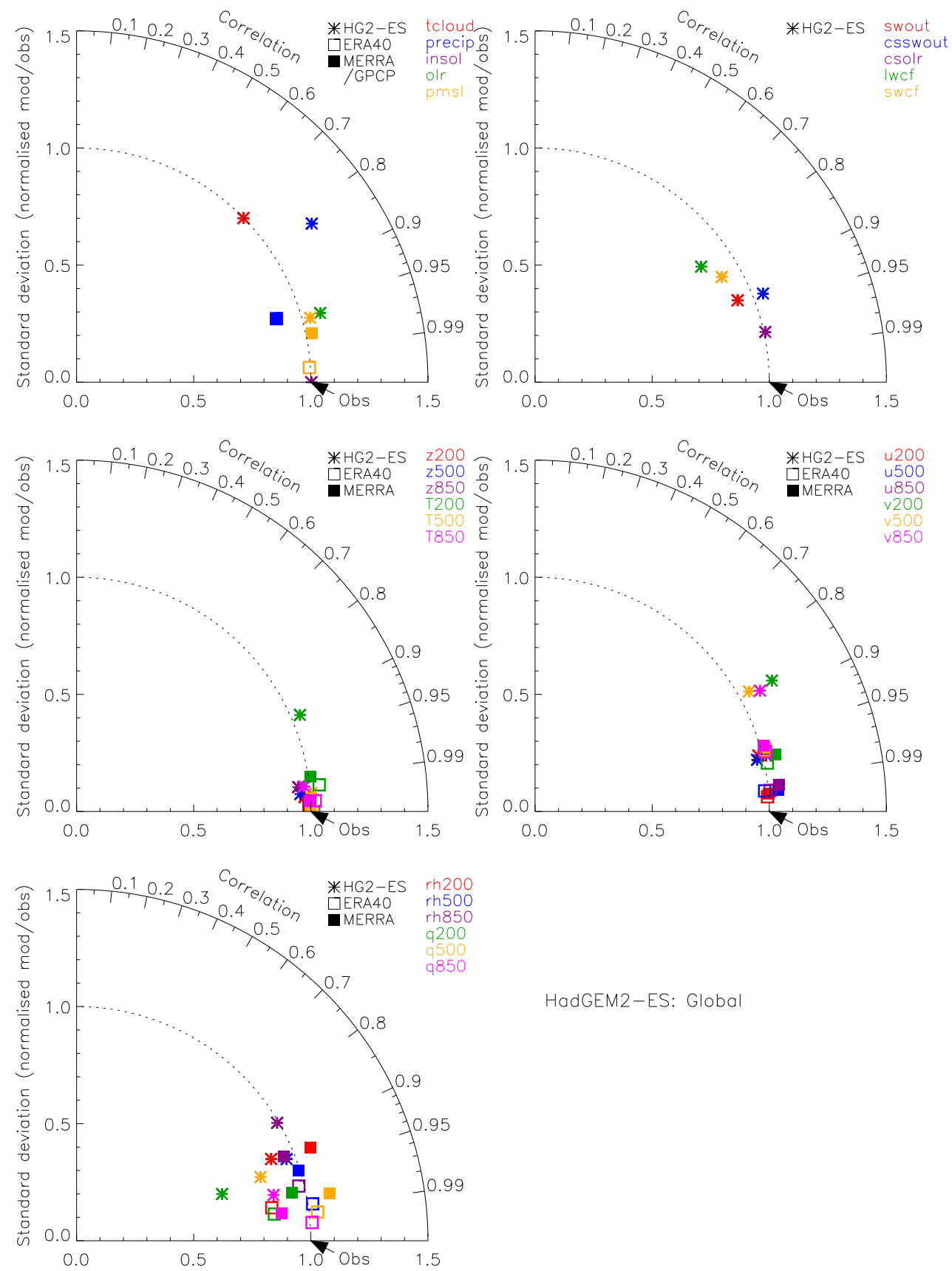

HadGEM2-ES: Global

Fig. 3a. Taylor diagrams showing a range of global fields from HadGEM2-ES. The reference climatologies (indicated by the "Obs" point) are ERA-Interim (Simmons et al., 2007a, b) for dynamical and thermodynamic variables, Earth Radiation Budget Experiment (ERBE; Harrison et al., 1990) data for radiation budget variables and the Climate Prediction Center (CPC) Merged Analysis of Precipitation (observation-only, CMAP/O; Xie and Arkin, 1997) for precipitation. Fields from ERA-40 (Uppala et al., 2005), the Modern Era Retrospective-analysis for Research and Applications (MERRA; Bosilovich et al., 2006, Bosilovich 2008) and the Global Precipitation Climatology Project (GPCP; Adler et al., 2003) are also included as data points for comparison. Values for the four seasons are combined so that any errors in the seasonal variation are also included. Variables shown are: total cloud amount (tcloud), precipitation (precip), pressure at mean sea level (pmsl), insolation (insol), outgoing longwave radiation (olr), outgoing shortwave radiation (swout), clear-sky outgoing shortwave radiation (csswout), clear-sky outgoing longwave radiation (csolr), longwave cloud forcing (lwcf), shortwave cloud forcing (swcf), geopotential height at 200, 500, $850 \mathrm{hPa}(\mathrm{z} 200, \mathrm{z} 500, \mathrm{z} 850)$, temperature at 200, 500, $850 \mathrm{hPa}(\mathrm{T} 200, \mathrm{~T} 500, \mathrm{~T} 850)$, zonal wind at 200, 500, 850 hPa (u200, u500, u850), meridional wind at 200, 500, $850 \mathrm{hPa}(\mathrm{v} 200, \mathrm{v} 500, \mathrm{v} 850)$, relative humidity at 200, 500, $850 \mathrm{hPa}(\mathrm{rh} 200, \mathrm{rh} 500$, rh850) and specific humidity at 200, 500, $850 \mathrm{hPa}$ (q200, q500, q850). 

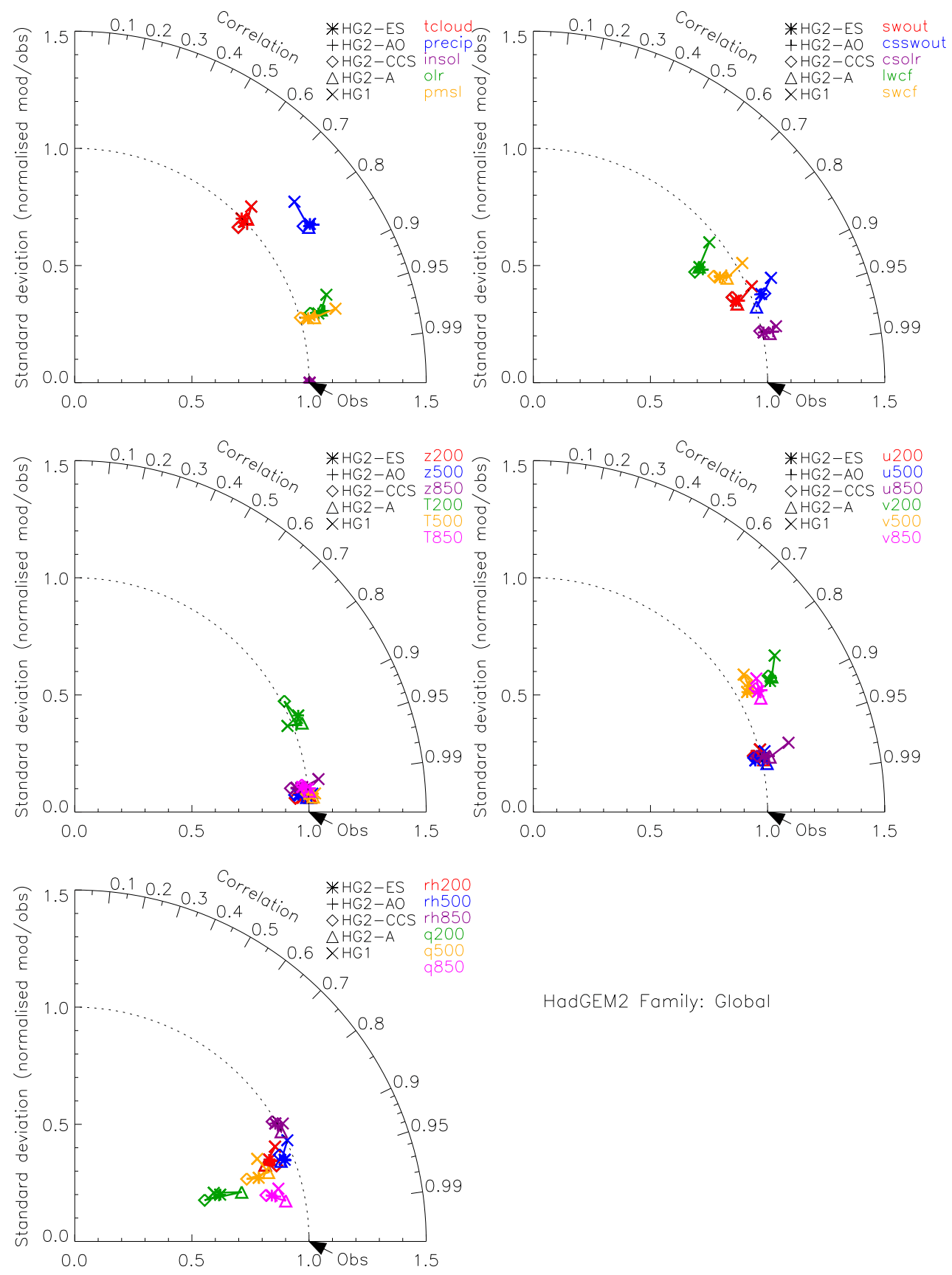

HadGEM2 Family: Global

Fig. 3b. As Fig. 3a but for the whole HadGEM2 Family; Global.

ERA-Interim through improved data assimilation and moist physics (Uppala et al., 2008), but it is clear that there is considerable uncertainty in reanalyses for these variables. The model results reflect this disparity between the different variables, with smaller differences from reanalyses in geopotential height, zonal wind and temperature (except at $200 \mathrm{hPa}$ ) and larger differences in meridional winds and humidities. The discrepancy in $200 \mathrm{hPa}$ temperature reflects the upper level temperature biases, particularly in the tropics, that were discussed by Martin et al. (2010). Precipitation is another variable for which global observations are subject to considerable uncertainty. The inclusion of Global Precipitation Climatology Project (GPCP v2; Adler et al., 2003) data compared against the CMAP (observation-only) dataset for a similar period (1979-1998) illustrates the uncertainty in precipitation observations which, over ocean, are largely based on satellite estimates. Yin et al. (2004) illustrate the discrepancy between the GPCP and CMAP datasets over oceans and 

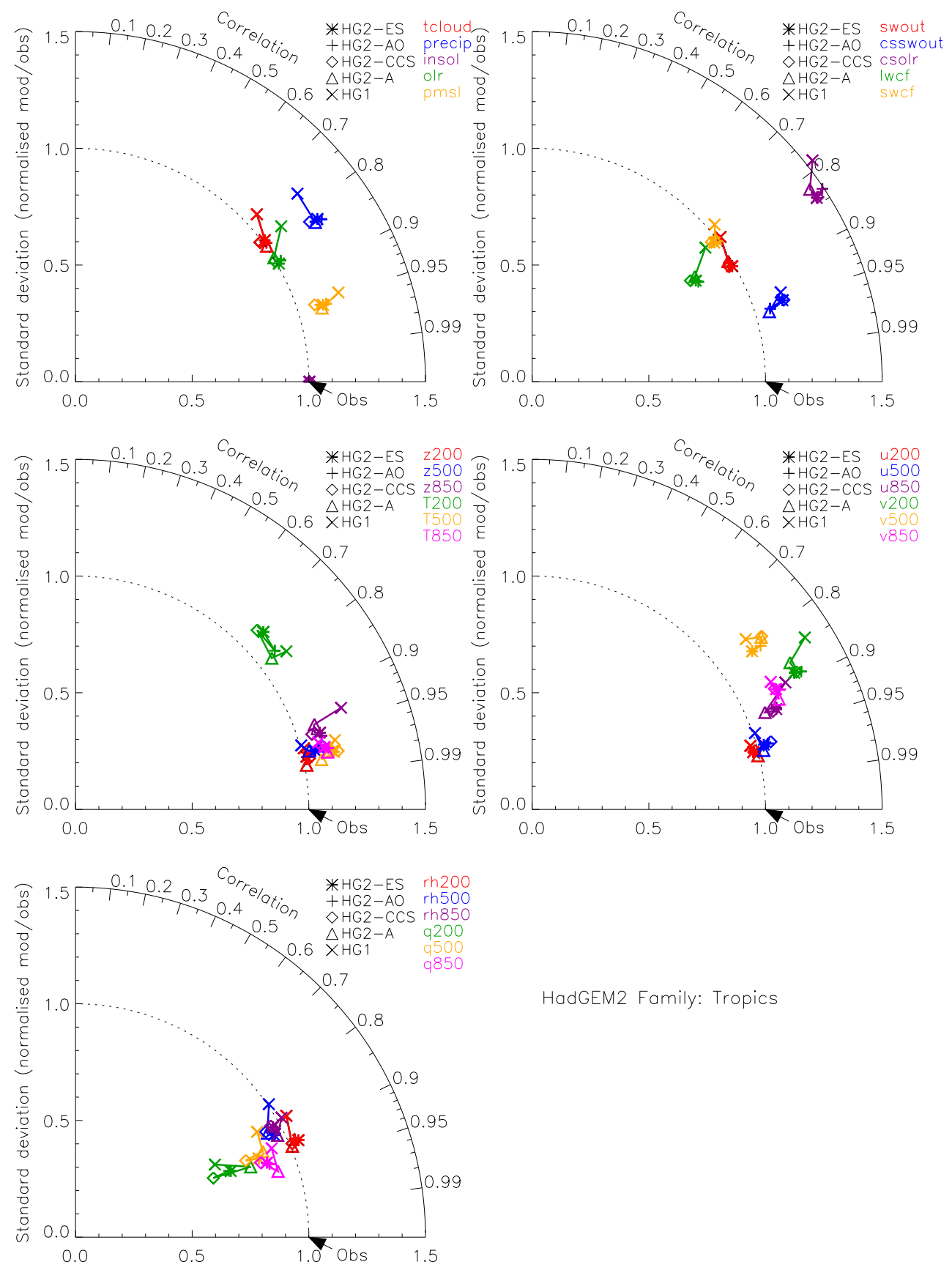

HadGEM2 Family: Tropics

Fig. 3c. HadGEM2 Family, Tropics ( $30 \mathrm{~S}$ to $30 \mathrm{~N}$ ).

at high latitudes. Our analysis shows particularly large differences in the Southern Hemisphere, and this is also where the model results differ the most from CMAP (see Fig. 3e).

However, Fig. 3b-e show that the HadGEM2 family represents a clear improvement over HadGEM1 for many of these climatological variables. Particular improvement is seen in the tropics, especially in tropical precipitation, humidity, cloud amount and radiative properties. Much of this is related to the changes made to the convective parametri- sation as described in Martin et al. (2010). In the Northern Hemisphere, there are improvements in clouds and radiative properties which are due to changes made to improve warm summer continental temperature biases (see Martin et al., 2010). Improvements to the representation of aerosols (see Sect. 4.2.3) also benefit the radiation metrics in both of these regions. Changes in the Southern Hemisphere are mixed and difficult to attribute to any particular change. Overall, however, Martin et al. (2010) showed that, in terms of simulating 

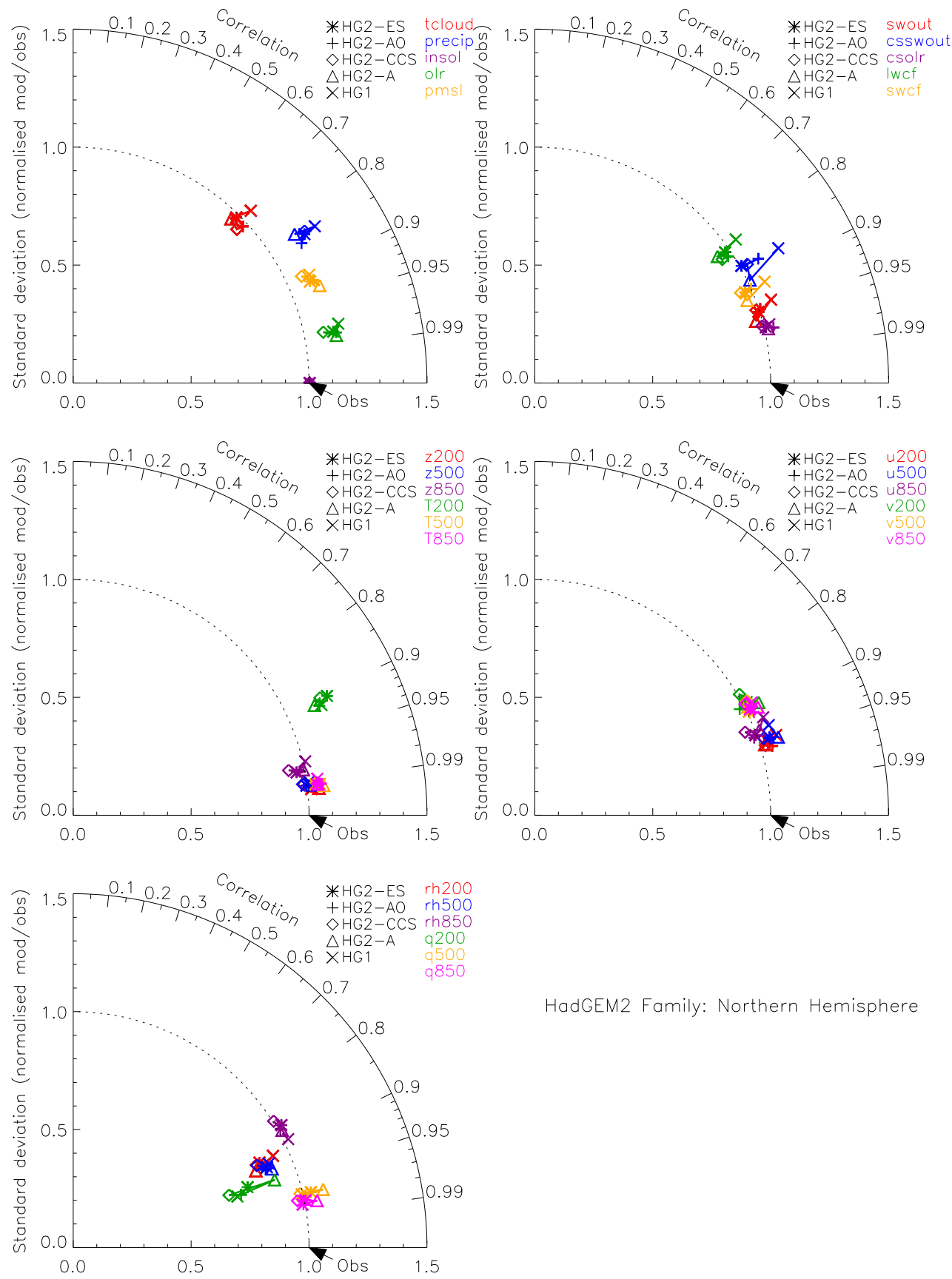

HadGEM2 Family: Northern Hemisphere

Fig. 3d. HadGEM2 Family, Northern Hemisphere (30 N to $70 \mathrm{~N})$.

present-day climate, HadGEM2-AO is in a leading position compared with other CMIP-3 models.

Figure $3 \mathrm{~b}-\mathrm{e}$ also illustrate the consistency between HadGEM 2 family members brought about by their sharing the same physical configuration, despite differences in functionality. This provides confidence that family members with reduced functionality can be used for specific scientific applications while still retaining traceability to the more complex members. It is also apparent that the seamless model development approach adopted in developing the HadGEM2 physical model was successful not only in reducing the systematic errors found in HadGEM1 but also in improving the model climatology as a whole.

In addition to examining climatological fields, it is useful to examine modes of variability in order to assess consistency between model family members. Analysis of Northern Hemisphere winter storm track activity (Fig. 4) shows reasonable agreement between the HadGEM2 family 

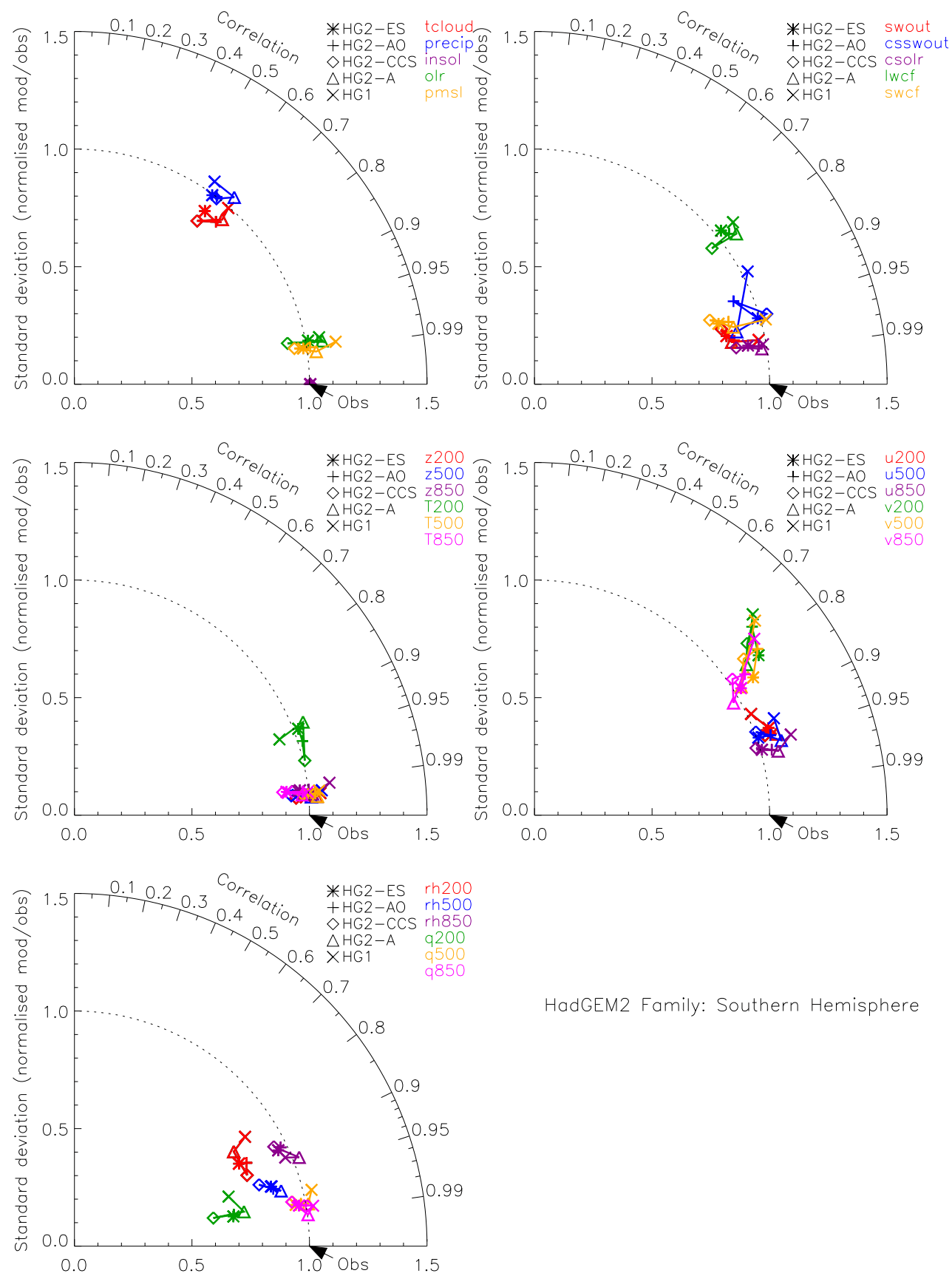

HadGEM2 Family: Southern Hemisphere

Fig. 3e. HadGEM2 Family Southern Hemisphere (30 S to $70 \mathrm{~S}$ ).

configurations and reanalyses in the location and extent of activity, and good agreement between the different family members. In a similar manner to HadGEM1, the Atlantic storm track shows limited extension into Europe (Ringer et al., 2006) in all of the HadGEM2 family configurations, although this is slightly better in HadGEM2-AO. In addition, there is more storm activity towards the eastern end of the Pacific storm track (Fig. 4), and the activity is slightly further north than in the reanalyses; these were also features of HadGEM1 (Ringer et al., 2006).
The analysis above shows that inclusion of a well-resolved stratosphere makes little difference to the mean climate or the climatology of the synoptic variability. However, several studies have indicated that the stratosphere plays a role in tropospheric variability (e.g. Scaife et al., 2005; Bell et al., 2009). Ineson and Scaife (2008) used a configuration of HadGAM1 which included the vertical extension as in HadGEM2-CCS to show that the stratosphere plays a role in the transition to cold conditions in northern Europe and mild conditions in southern Europe in late winter during El 
(a) ERA40
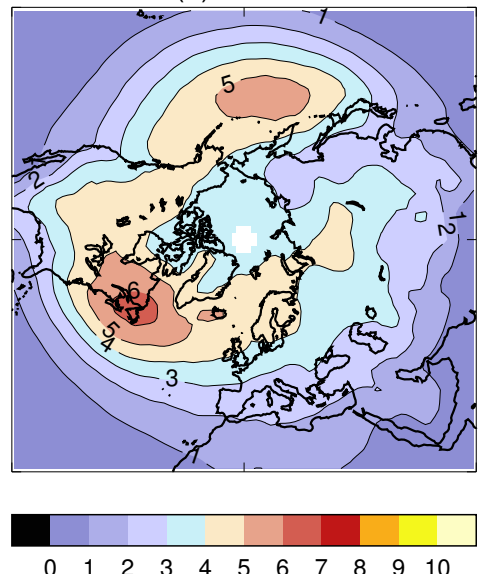

(c) HadGEM2-ES
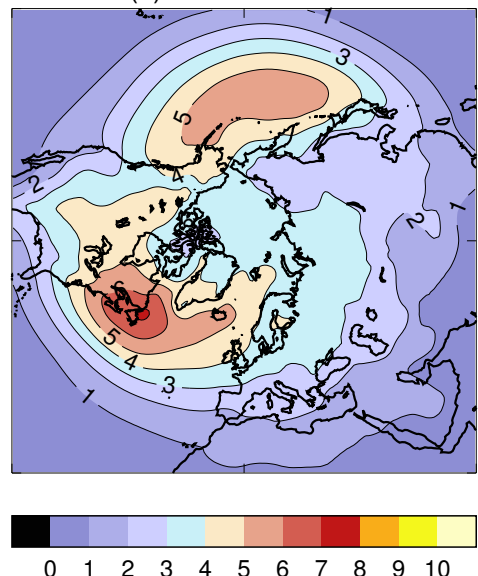

(e) HadGEM2-CCS
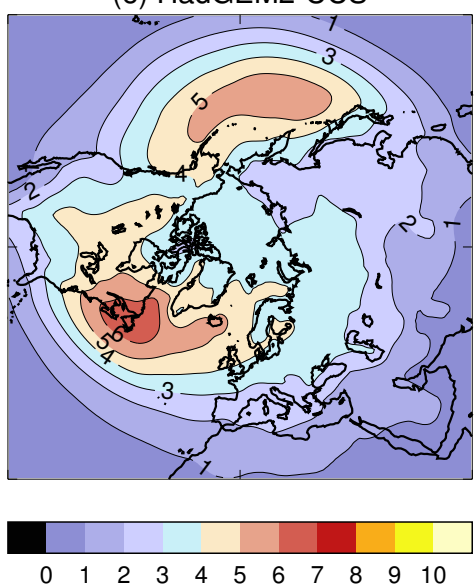

(b) HadGEM2-AO
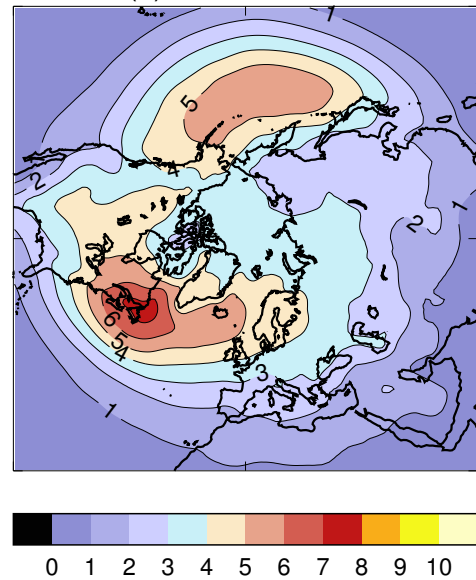

(d) HadGEM2-CC

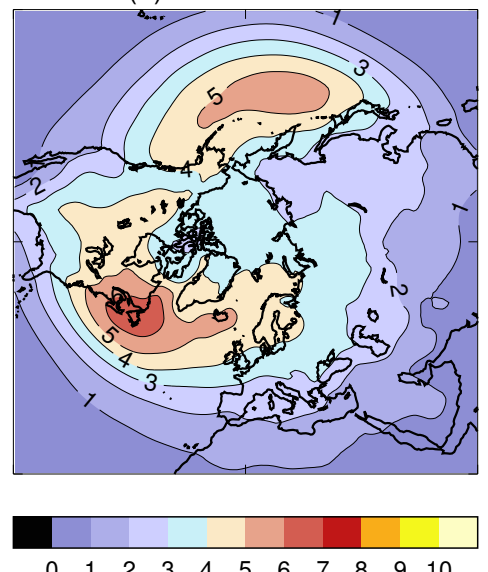

$\begin{array}{llllllllllll}0 & 1 & 2 & 3 & 4 & 5 & 6 & 7 & 8 & 9 & 10\end{array}$

Fig. 4. Northern Hemisphere winter (December to February: DJF) storm track activity in HadGEM2 family models, measured using the Blackmon band-pass filter method (Blackmon, 1976). (a) ERA40; (b) HadGEM2-AO (RMS diff from ERA40 $=0.385 \mathrm{hPa}$, bias $=-0.058 \mathrm{hPa}) ; \quad$ (c) HadGEM2-ES (RMS diff $=0.356 \mathrm{hPa}$, bias $=-0.119 \mathrm{hPa}) ;$ (d) HadGEM2-CC (RMS diff $=0.355 \mathrm{hPa}$, bias $=-0.146 \mathrm{hPa})$; $(\mathbf{e})$ HadGEM2-CCS $(\mathrm{RMS}$ diff $=0.350 \mathrm{hPa}$, bias $=-0.122 \mathrm{hPa})$. Values are variances of the time filtered daily mean PMSL in hPa. The time filter is 2-6 days and isolates the synoptic variability. Model analysis includes 3 ensemble members each for the historical runs, covering the period 1960-1990, and $30 \mathrm{yr}$ from the HadGEM2-AO present-day control run. ERA40 data from 1960-1990 are used for comparison. RMS differences and biases are calculated over the region between $30 \mathrm{~N}-80 \mathrm{~N}$. 


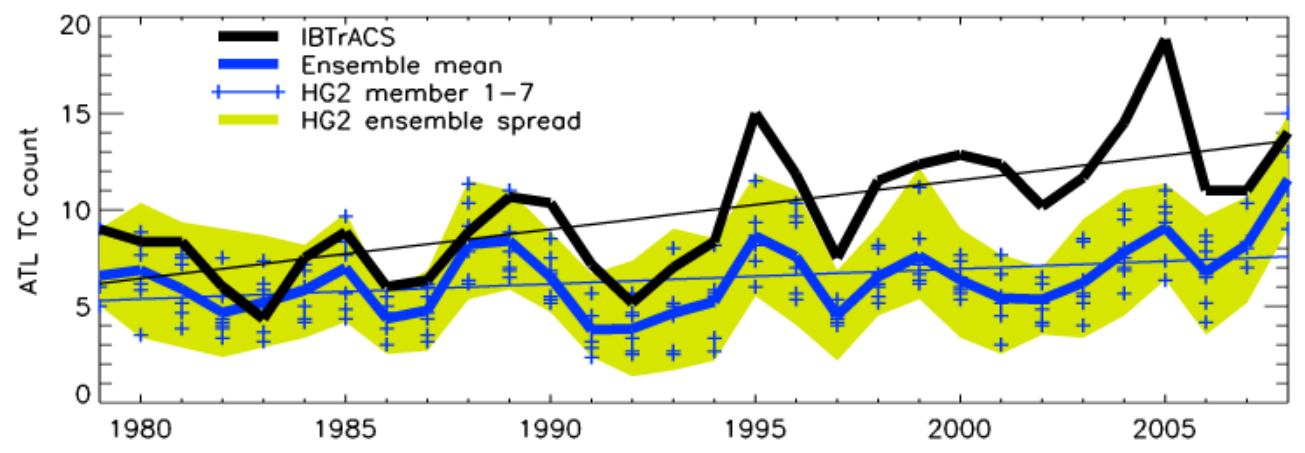

Fig. 5. Annual mean count of tropical cyclones in the North Atlantic from a 7-member ensemble of HadGEM2-A compared with counts from the observed IBTrACS database (Knapp et al., 2010). The curves have a 1-2-1 smoothing applied, and the symbols represent each ensemble member, while the straight lines are the trend over this period. Analysis used the TRACK feature tracking method (Hodges, 1994), where centres of high vorticity are tracked on a T42 grid, together with a vertical check to ensure a warm core, and each tropical cyclone must last at least 2 days and form south of $30 \mathrm{~N}$ - the latter is also enforced on the IBTrACS data, where only named storms are used (maximum wind greater than $30 \mathrm{kts}$ ). Analysis of three different reanalyses datasets using the same methodology gives extremely good agreement with the IBTrACS timeseries (correlation over 0.9).

Niño years. Recent work using vertically-extended models (e.g. Scaife et al., 2011) also suggests that changes in stratospheric circulation could play a significant role in future climate change in the extratropics. Such studies are likely to be repeated with the CMIP-5 ensemble of vertically-extended climate configurations when these are available.

As a measure of tropical variability, the annual mean count of tropical cyclones in the North Atlantic, from a sevenmember ensemble of HadGEM2-A runs forced by observed SSTs for the period 1979-2008, is shown in Fig. 5. It is clear that although this configuration tends to underestimate the total tropical cyclone counts, and does not represent the overall increase of tropical storms over this period as seen in the observations, it can capture a significant amount of the interannual variability in tropical cyclones (correlation of 0.76 between ensemble mean and observed timeseries). This is similar to the correlation obtained by Zhao et al. (2009) using a model with a much finer $(50 \mathrm{~km})$ horizontal resolution. This may be because, in the Atlantic, tropical cyclone variability is strongly cross-correlated with Atlantic interannual SST variability, wind shear and other factors such as the Atlantic Multidecadal Oscillation (e.g. Smith et al., 2010), factors which don't require high resolution. Using observed SST forcing, and a large ensemble, are both likely to increase the correlation by improving the forced signal to internal variability noise. Similar analysis of tropical cyclone numbers in the coupled HadGEM2 configurations (not shown) show further underestimations of activity, due mainly to cold SST biases in the region (see Sect. 4.2.5).

\subsubsection{Land surface and hydrology}

Many of the changes made to the atmosphere and land surface parametrisations were aimed at reducing summer warm and dry surface biases in the Northern Hemisphere continental interiors. Martin et al. (2010) showed that the changes to surface runoff, aerosols and convective cloud amounts seen by the radiation scheme reduce these biases considerably. Additional benefit is provided by the new large-scale hydrology scheme, which was included in order to allow subgridscale soil moisture variability (Clark and Gedney, 2008). This scheme facilitates the representation of variations in the extent of wetlands, from which methane is emitted (Gedney et al. 2004). Further improvement in the summer surface temperatures is seen when the large-scale hydrology is included. As also mentioned in Martin et al. (2010), improvements to the surface albedo have been made (see Appendix A, Table A2) which provide an additional benefit, particularly in the Saharan region. A comparison of boreal summer near-surface temperatures between HadGEM2-AO and HadGEM1 (Fig. 6) shows overall improvement in the new configuration, although a warm bias remains in the Northern Hemisphere continental regions and a cold bias over South America is rather worse.

A primary driver for improving the warm and dry biases in the physical model is to provide a more suitable and realistic surface continental climate for the growth and persistence of characteristic vegetation types when coupled to an interactive vegetation model as part of the coupling to a full EarthSystem model. Martin et al. (2010) showed that the package of changes to both the atmosphere and land surface components included in HadGEM2-AO improved the simulated vegetation coverage and hence the net primary productivity (NPP). This is the difference between the total carbon assimilated by photosynthesis and the carbon lost through plant 


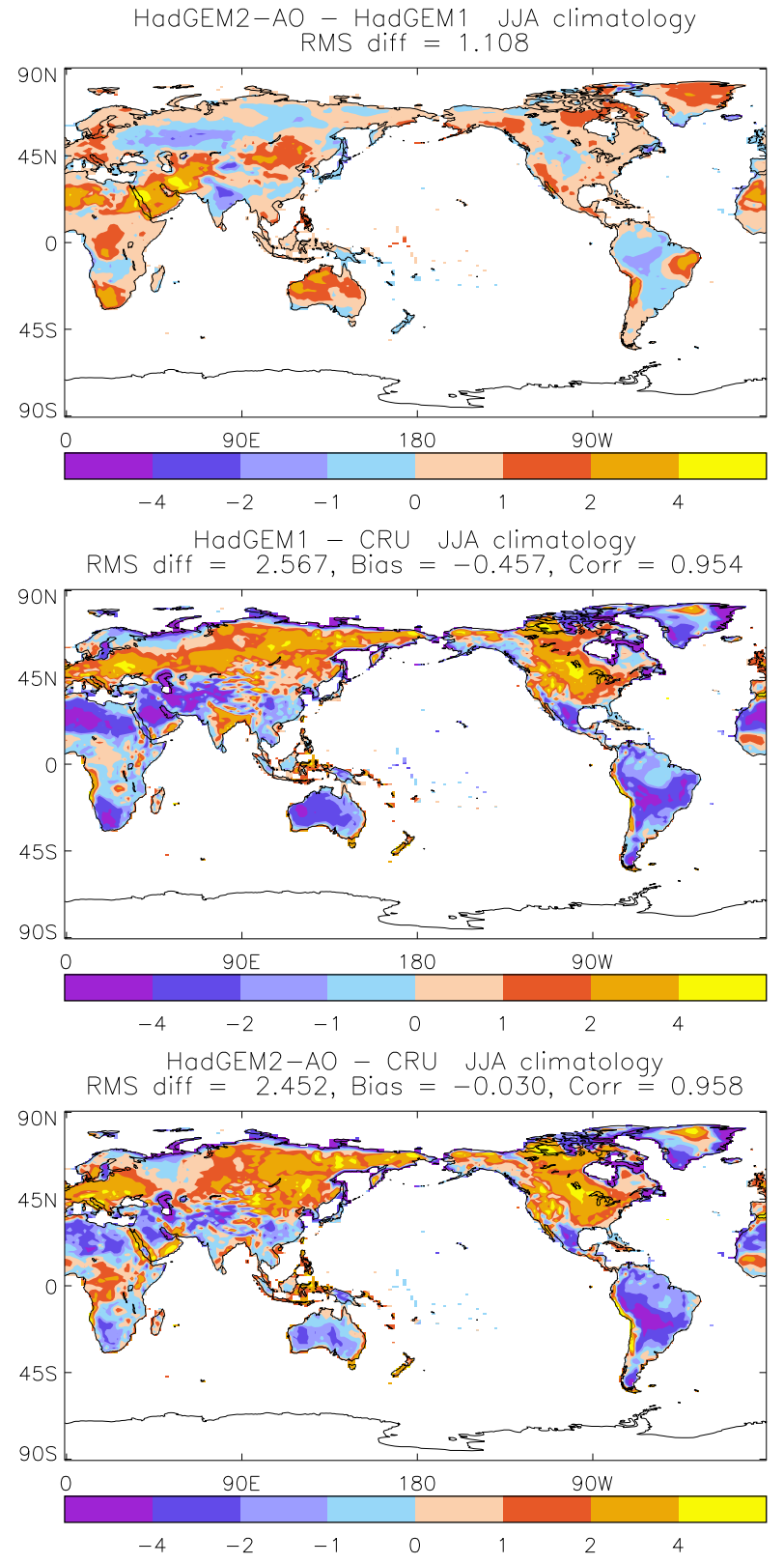

Fig. 6. Comparison of $1.5 \mathrm{~m}$ temperature in boreal summer (JuneAugust: JJA) between HadGEM1 and HadGEM2-AO. Observed climatology is from the Climatic Research Unit, Norwich, United Kingdom (CRU; New et al., 1999).

respiration. NPP therefore represents the net uptake of carbon by the vegetation, so it is an important component of the terrestrial carbon cycle. Whereas HadGEM1 showed significant negative biases in NPP over both continental regions, including some regions where the conditions were unsuitable for any vegetation growth, with HadGEM2 the biases are much smaller. Improvements in this diagnostic suggest that the physical model is now more suitable for Earth Sys-
Table 2. Global net water fluxes in various sub-components of HadGEM2-AO, before and after corrections were made to the coupling between the river routing and land surface schemes, to the treatment of runoff into inland basins and to lake evaporation. Also shown is the impact of correcting the adjustment to the snow mass $\&$ ice sheet freshwater budget to account for lack of parametrised iceberg calving (see Sect. 4.2.5). Values in $\mathrm{mSv}$.

\begin{tabular}{lrr}
\hline Sub-component & $\begin{array}{r}\text { Before } \\
\text { corrections }\end{array}$ & $\begin{array}{r}\text { After } \\
\text { corrections }\end{array}$ \\
\hline Atmosphere & -12 & -11 \\
Snow mass \& ice sheets & -64 & -1 \\
Sea ice & 0 & 8 \\
Soil moisture & -85 & 4 \\
River routing & 181 & -3 \\
Ocean & -20 & 3 \\
\hline
\end{tabular}

tem modelling. Further discussion of the NPP simulated by HadGEM2-ES is included in Sect. 4.2.7.

In order to simulate changes in sea level, and changes in ocean salinity, it is necessary to account for the surface runoff and river flow. The HadGEM1 surface scheme had inconsistencies in the coupling between the river routing scheme and the land surface model, and a loss of freshwater due to runoff into inland basins and evaporation from lakes (see Appendix A, Table A2). Correction of these inconsistencies improves the water conservation in the soil moisture and river routing sub-components (see Table 2).

\subsubsection{Aerosols}

The aerosol module of HadGEM2 is described in Bellouin et al. (2011) and contains numerical representations for up to seven tropospheric aerosol species: ammonium sulphate, mineral dust, sea-salt, fossil-fuel black carbon, fossil-fuel organic carbon, biomass-burning aerosols and secondary organic (also called biogenic) aerosols. The representation of the sulphur cycle can make use of DMS emissions from the ocean biogeochemistry model, and chemical oxidants $(\mathrm{OH}$, $\mathrm{H}_{2} \mathrm{O}_{2}, \mathrm{HO}_{2}, \mathrm{O}_{3}$ ) from the tropospheric chemistry model. If those models are not included in the simulation, DMS emissions and chemical oxidants are prescribed monthly. The direct radiative effect due to scattering and absorption of radiation by all eight aerosol species is included. All aerosol species except mineral dust and fossil-fuel black carbon are considered to be hydrophilic, act as cloud condensation nuclei, and contribute to both the first and second indirect effects on clouds, treating the aerosols as an external mixture (Jones et al., 2001). The cloud droplet number concentration $(\mathrm{CDNC})$ is calculated from the number concentration of the accumulation and dissolved modes of hygroscopic aerosols. For the first indirect effect, the radiation scheme uses the CDNC to obtain the cloud droplet effective radius. 


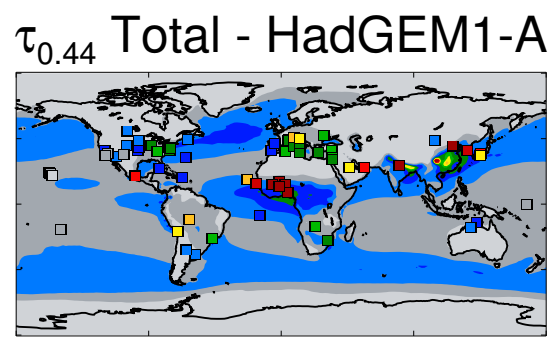

Global model mean: 0.083 , RMSE: 0.22

$\begin{array}{llllll}0 & 0.1 & 0.2 & 0.3 & 0.4 & 0.5\end{array}$

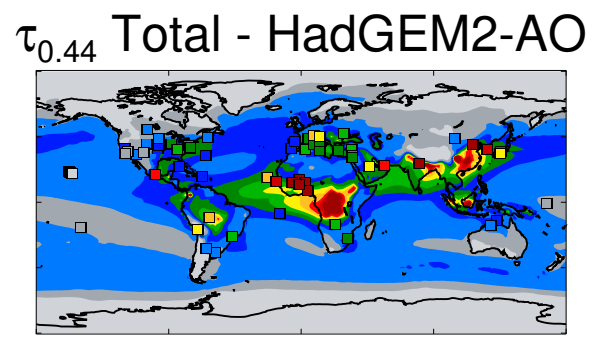

Global model mean: 0.133, RMSE: 0.15

$\begin{array}{llllll}0 & 0.1 & 0.2 & 0.3 & 0.4 & 0.5\end{array}$

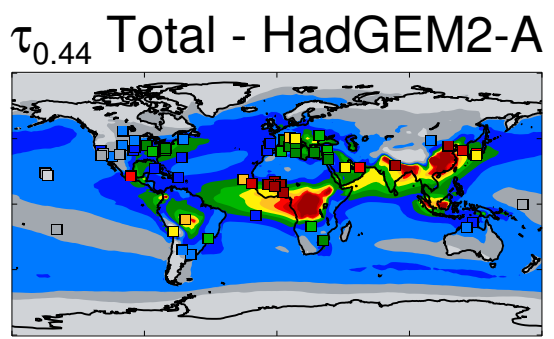

Global model mean: 0.139, RMSE: 0.13

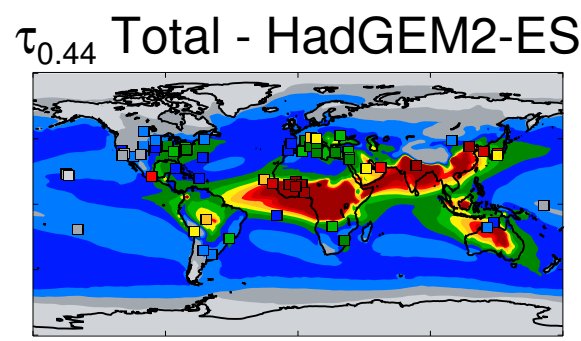

Global model mean: 0.184, RMSE: 0.11

$\begin{array}{llllll}0 & 0.1 & 0.2 & 0.3 & 0.4 & 0.5\end{array}$

Fig. 7. Annual-averaged distributions of total aerosol optical depth at 0.44 microns in HadGEM1-A and HadGEM2 family member models for present-day conditions. Square boxes show averaged AERONET measurements for the period 1998-2002, using the same colour scale. The root-mean square error (RMSE) is computed from AERONET measurements and the model simulation in gridboxes that contain the AERONET sites.
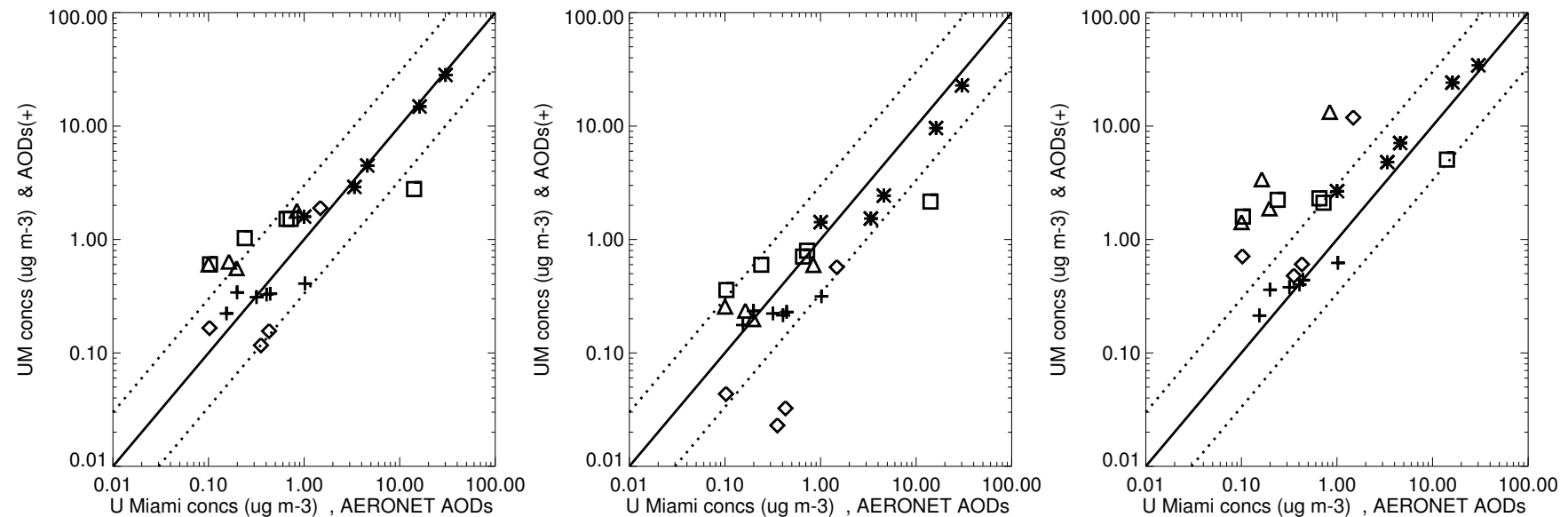

Fig. 8. Comparison of modeled and observed near surface dust concentrations and total aerosol optical depths at $440 \mathrm{~nm}$ for HadGEM2-A (left), HadGEM2-AO (centre) and HadGEM2-ES (right). Observed optical depths are from AERONET stations in dust-dominated regions and concentrations from stations of the University of Miami network (with thanks to J. M. Prospero and D. L. Savoie). Symbols indicate: crosses - AODs, stars - Atlantic concentrations, squares - N Pacific concentrations, triangles - S Pacific concentrations, diamonds - Southern Ocean concentrations. 

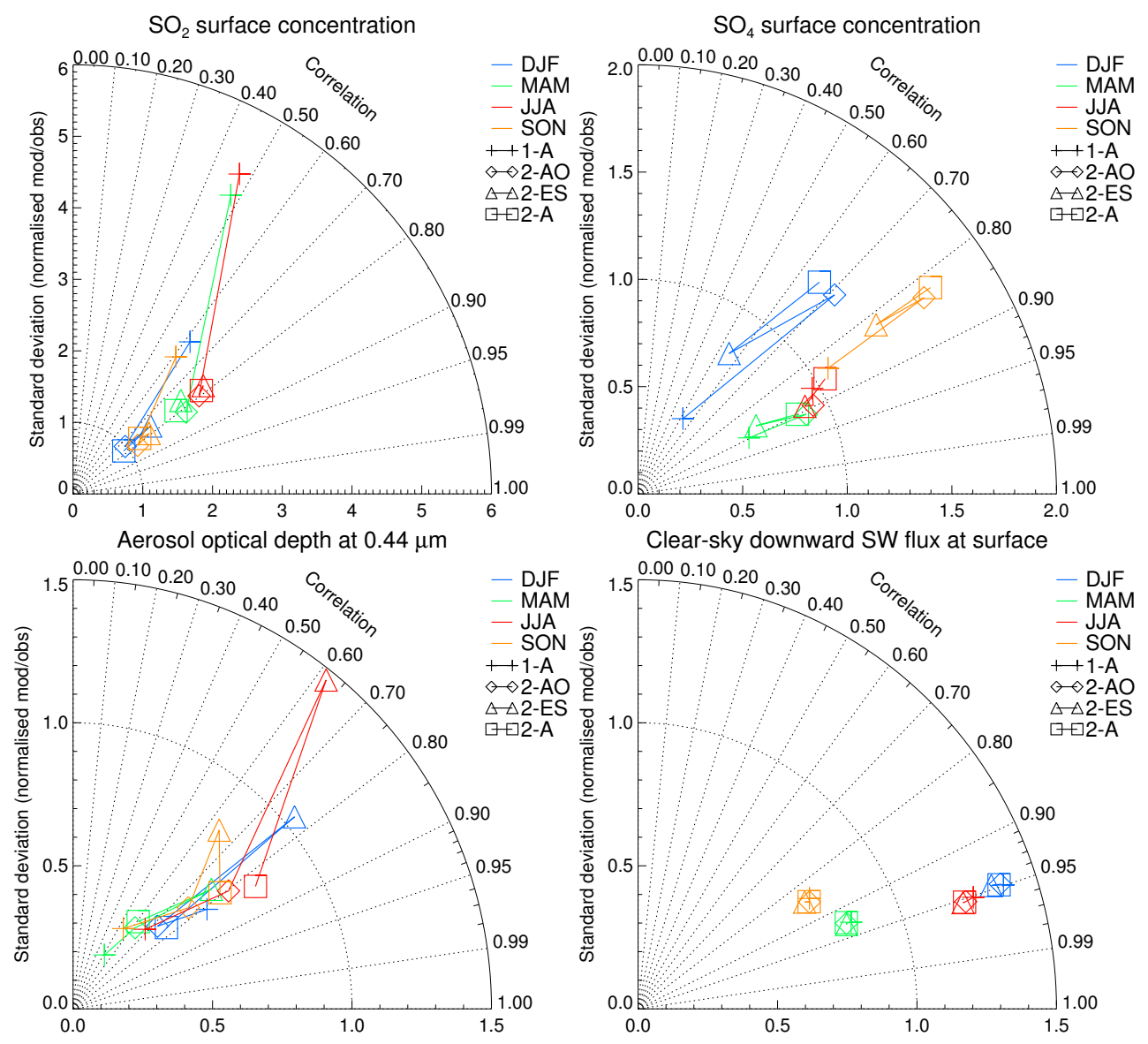

Fig. 9. Taylor diagrams for seasonally-averaged surface concentrations of (a) sulphur dioxide and (b) sulphate aerosol, (c) total aerosol optical depth at $0.44 \mu \mathrm{m}$, and (d) clear-sky shortwave flux at the surface as modelled by HadGEM1 and HadGEM2 configurations using emission datasets for the year 2000 (so-called "present-day" emissions), compared with climatologies of ground-based measurements for 1998-2002. $\mathrm{SO}_{2}$ surface concentrations are provided by the European Monitoring and Evaluation Programme (EMEP; Hjellbrekke, 2002) and Clean Air Status and Trends Network (CASTNET; Mueller, 2003), which cover Europe and North America, respectively. $\mathrm{SO}_{4}$ surface concentrations are measured by EMEP, CASTNET, and IMPROVE (Interagency Monitoring of Protected Visual Environments, North America; Malm et al., 1994). Total AODs at $0.44 \mu \mathrm{m}$ are given by the Aerosol Robotic Network (AERONET; Holben et al., 2001) at 67 sites worldwide. Clear-sky downward surface fluxes are derived from measurements at 24 Baseline Surface Radiation Network (BSRN) sites (Ohmura et al., 1998)

For the second indirect effects, the large-scale precipitation scheme uses the CDNC to compute the autoconversion rate of cloud water to rainwater.

One rationale behind developing further the aerosol schemes in the MetUM was to improve the total aerosol optical depth (AOD) distribution. As shown in Fig. 7, total present-day AOD was low in HadGEM1 compared to AERONET observations (Holben et al., 2001), with only a few regions associated with large optical depths. Distributions for the HadGEM2 family members, shown in the same figure, compare much better with observations, with smaller root-mean square errors. However, HadGEM2-ES shows significantly higher AOD in those regions where the interactive vegetation scheme tends to overestimate bare soil fraction leading to underestimation of soil moisture and overestimation of near-surface winds, all of which lead to anoma- lously high mineral dust production, especially in arid and semi-arid areas, such as parts of Australia and the Indian subcontinent.

Mineral dust aerosol was included as an integral part of the standard model for the first time in HadGEM2. The introduction of the scheme permits the simulation of mineral dust and its effect on model climate via radiative effects, and in HadGEM2-ES via interaction with the ocean carbon cycle. The dust model is based on that designed for use with HadAM3 (Woodward, 2001), with significant developments to the emission scheme (Woodward, 2011). The scheme contains two tuneable parameters (multipliers to friction velocity and soil moisture) set differently for HadGEM2-A compared with HadGEM2-AO and HadGEM2-ES, due to the differences in model climates. The use of the same setting in the two coupled models, though a compromise between 

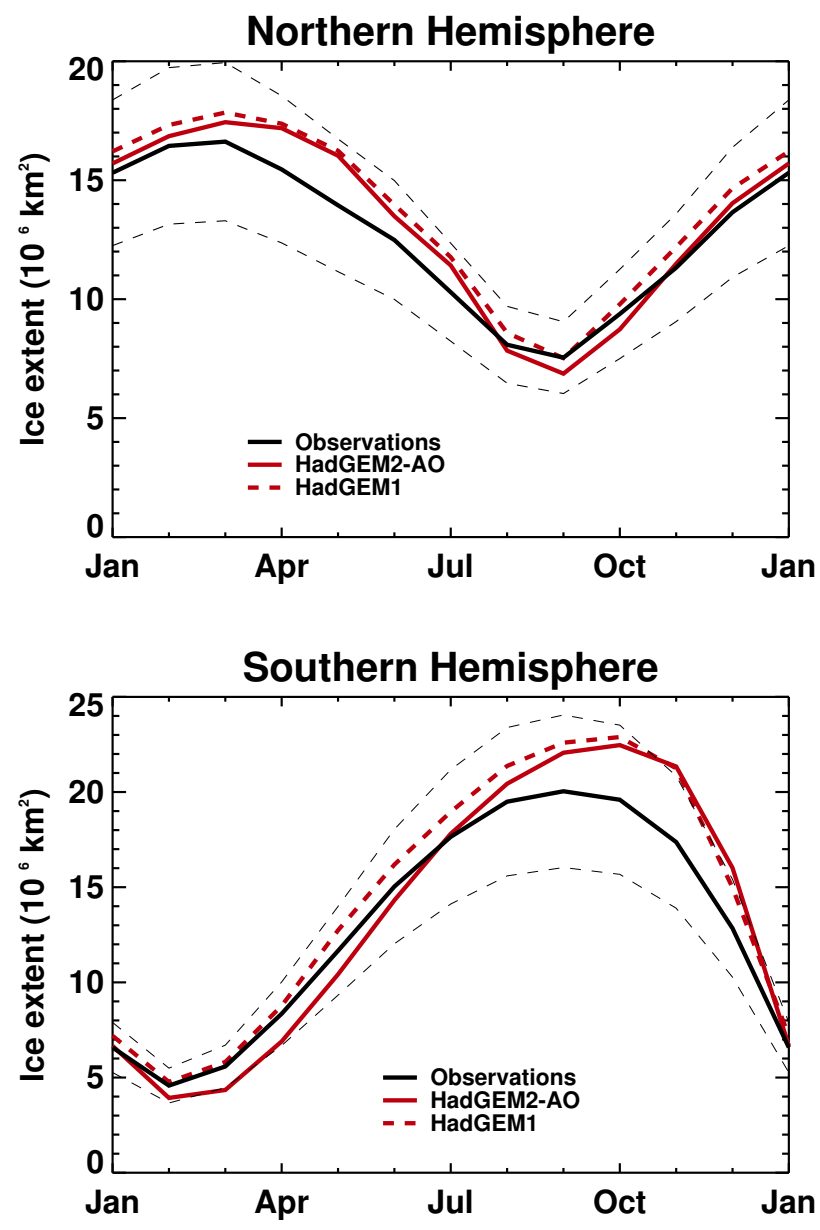

Fig. 10. Seasonal cycle of the sea ice extent $\left(10^{6} \mathrm{~km}^{2}\right)$ for HadGEM2-AO (red solid line) and HadGEM1 (red dashed line) for the Northern Hemisphere and the Southern Hemisphere. Shown together with $20 \mathrm{yr}$ mean values of the HadISST observational data set (Rayner et al., 2003) (black line) for 1980-1999. The black dashed lines indicate the observed values $\pm 20 \%$.

the optimum for each, facilitates comparison between them. A comparison of simulated dust fields with observation is shown in Fig. 8. The total AODs in the dust-dominated regions agree well with observations and there is reasonable consistency between the HadGEM2 family members. The dust concentrations at remote island sites also compare well in HadGEM2-A with those observed. In HadGEM2ES these concentrations are somewhat over-estimated, as a result of the overestimation of bare soil fraction discussed above; in HadGEM2-AO concentrations are slightly underestimated, as a result of using the same tuning parameters as in HadGEM2-ES.

To assess in more detail the performance of the HadGEM2 aerosol simulations and progress made since HadGEM1, modelled surface concentrations of sulphur dioxide $\left(\mathrm{SO}_{2}\right)$ and sulphate aerosol $\left(\mathrm{SO}_{4}\right)$, total AOD, and clear-sky downward shortwave flux at the surface are compared against sea- sonal averages from ground-based measurement networks. Comparisons against those largely ground-based measurements confirm that aerosol-related variables are indeed improved in HadGEM2 compared with HadGEM1 (Fig. 9). The underestimation of sulphate concentrations in Northern Hemisphere $(\mathrm{NH})$ winter is partially resolved by the revision of oxidation pathways and new $\mathrm{SO}_{2}$ emission datasets. For $\mathrm{SO}_{2}$ surface concentrations, the inclusion of oxidation of $\mathrm{SO}_{2}$ by ozone has a positive impact: HadGEM1 is the worst model and metrics are much improved in HadGEM2 (Fig. 9a). Within the HadGEM2 family, members behave similarly, although HadGEM2-ES has slightly worse performance in $\mathrm{NH}$ winter in spite of using interactive oxidants, suggesting that other meteorological biases may play a role. $\mathrm{SO}_{4}$ surface concentrations do not show a uniform improvement, with performance depending on the season and model (Fig. 9b). Solving the underestimated concentrations over $\mathrm{NH}$ continents in winter yields improved normalised standard deviation and spatial correlation for HadGEM2 family members. For NH summer, all models perform similarly, while HadGEM2 configurations show poorer results in $\mathrm{NH}$ autumn.

For total aerosol optical depth, normalised standard deviations are much improved in HadGEM2 compared with HadGEM1 (Fig. 9c), although as mentioned above, HadGEM2-ES behaves poorly in NH summer due to overestimated mineral dust optical depths. For surface clearsky shortwave flux, metrics are similar for all models, although a small improvement towards better normalised standard deviations between HadGEM1 and HadGEM2 can be identified (Fig. 9d). This metric is less affected by changes in aerosol, due to the locations of observational data used, from the Baseline Surface Radiation Network (Ohmura et al., 1998). Overall, efforts in improving aerosol representations for HadGEM2 are successful.

\subsubsection{Sea ice}

The seasonal cycle of the sea ice extent for HadGEM2-AO compares well with observations (Fig. 10). The ice extent remains within $20 \%$ of the observed values for all 12 months in the Arctic and for 11 months in the Antarctic. The model ice extent is too great in winter in both hemispheres.

The model ice thickness (Fig. 11, panel i) increases across the Arctic towards the northern coasts of Greenland and the Canadian Archipelago in agreement with observations (Rothrock et al., 2008; Laxon et al., 2003; Bourke and Garrett, 1986). The submarine data multiple regression analysis of Rothrock et al. (2008) is shown in Fig. 11 panel (iii) for comparison and the differences are shown in Fig. 11 panel (iv). Over the observed region, the model mean ice thickness is $0.57 \mathrm{~m}$ thinner than the observations. In particular, the model ice is too thin in the region of the thickest observations, suggesting there may be insufficient ridging in this area of the model. 
i)
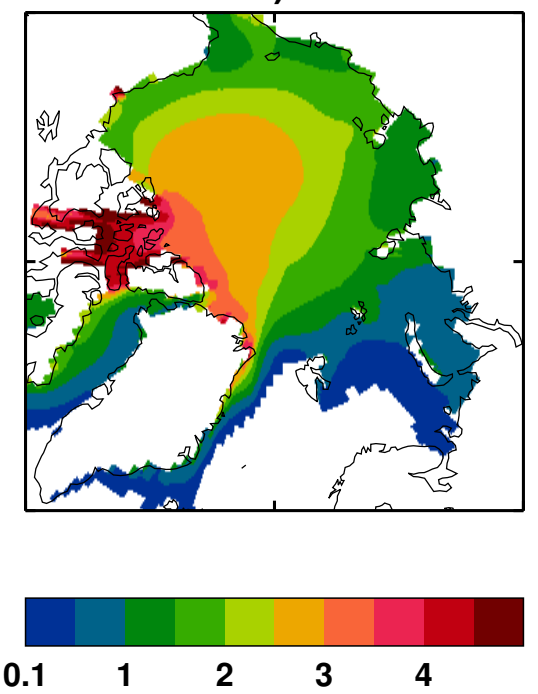

iii)
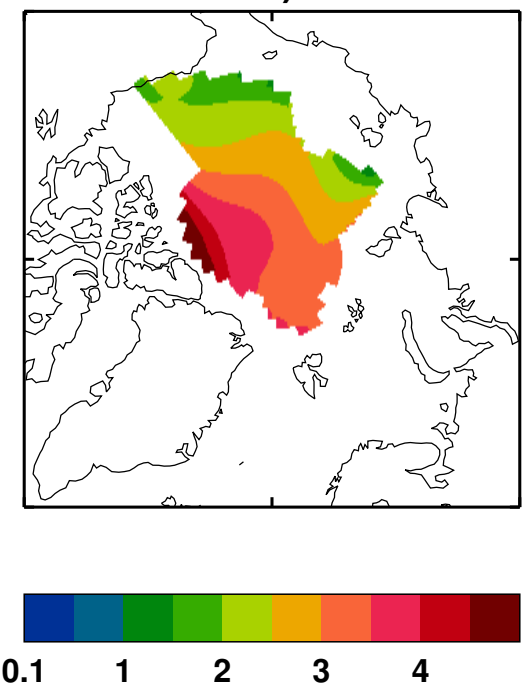

ii)
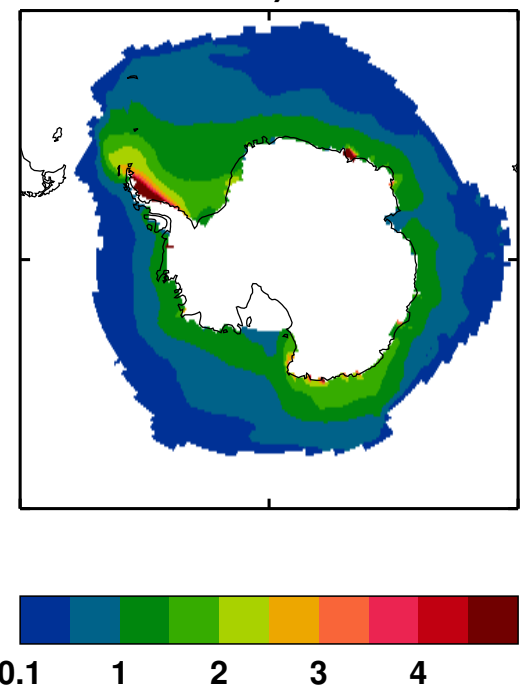

iv)
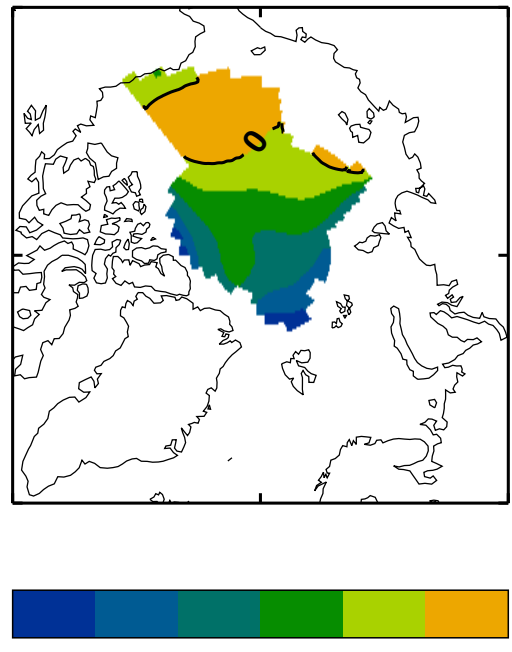

$-2$

$-1$

0

Fig. 11. Annual mean ice thickness plots (m): (i) HadGEM2-AO Arctic (including open water); (ii) HadGEM2-AO Antarctic (excluding open water) which can be compared with Fig. 6 of Worby et al. (2008); (iii) Submarine data analysis of Rothrock et al. (2008); (iv) Difference between the model and submarine data analysis. The submarine data presented here from Rothrock et al. (2008) is their multiple regression equation which has been evaluated on the model grid, bias corrected and converted from draft to thickness. Statistics for panel (iv): bias $=-0.57 \mathrm{~m}$, RMS difference $=0.89 \mathrm{~m}$ and correlation $=0.42$.

The annual mean map of the Antarctic ice thickness (Fig. 11, panel ii) is broadly consistent with the ship based observational dataset of Worby et al. (2008), with the exceptions of the model ice being too thin in the eastern Ross Sea and excessively thick in the western Weddell Sea. The model has no representation of the Larsen Ice Shelf and consequently sea ice becomes lodged against the Antarctic Peninsula where it continues to grow to an excessive thickness, through snow fall creating snow ice.
The sea ice in HadGEM2-AO is broadly similar to HadGEM1 in the model experiments analysed here. The HadGEM1 extents (Fig. 10) are slightly higher, especially around the time of the summer minima and subsequent freeze-up in both hemispheres. The spatial patterns of ice thickness in HadGEM2-AO strongly resemble HadGEM1 (McLaren et al., 2006). However the ice is thinner in HadGEM2-AO; for example, the ice is $30 \mathrm{~cm}$ thinner than HadGEM1 in the Central Arctic region (defined as $65-80^{\circ}$, $105-240^{\circ} \mathrm{E}$ plus the region north of $80^{\circ} \mathrm{N}$ ). HadGEM2-AO 

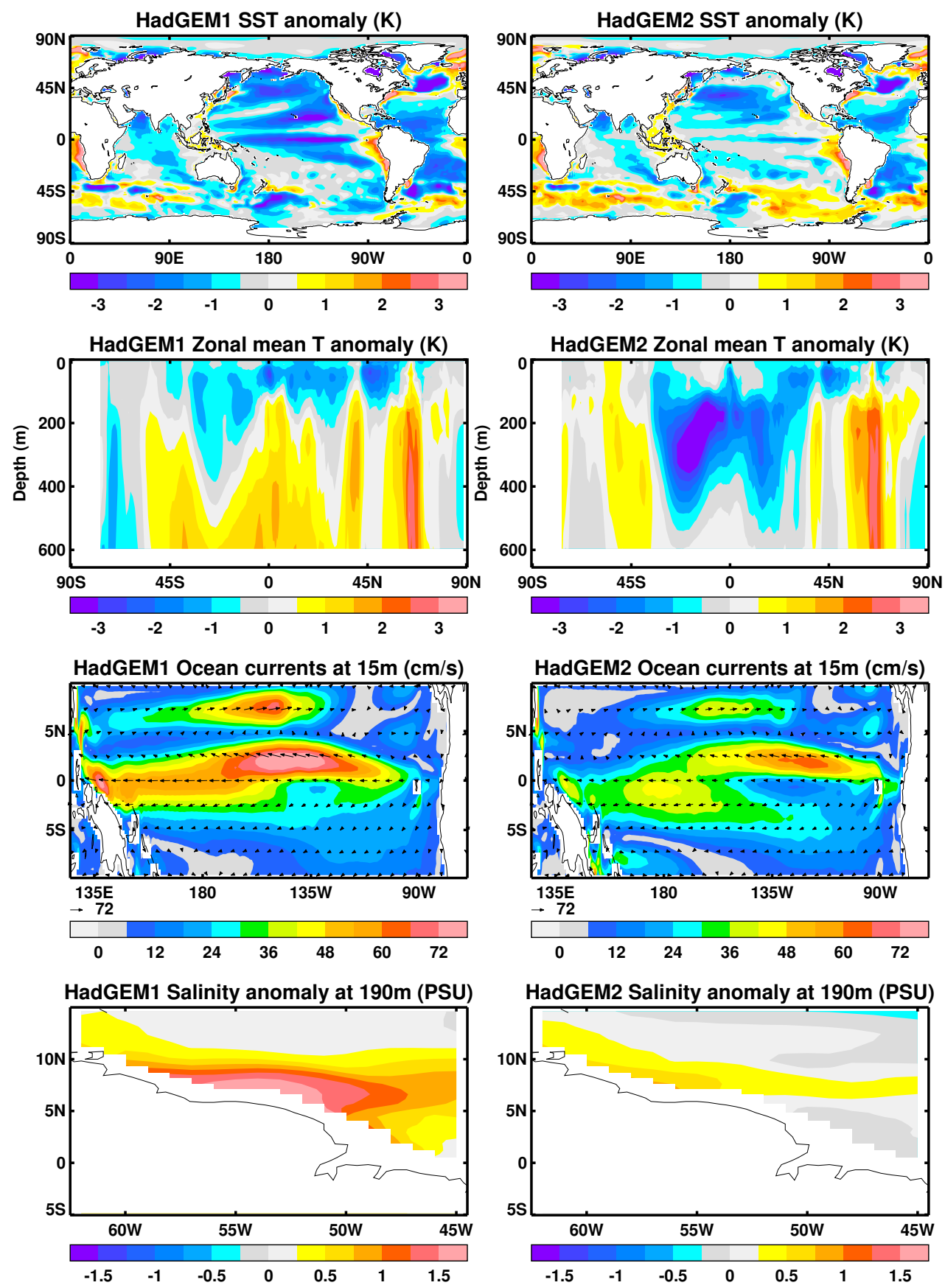

Fig. 12. Comparison of various mean fields from HadGEM1 (left hand column) and HadGEM2-AO (right hand column). Top panels: sea surface temperature anomaly with respect to Levitus (Levitus et al., 1998) climatology; for HadGEM1, bias = -0.68 K, RMS difference $=1.37 \mathrm{~K}$ and correlation $=0.99$; for HadGEM2, bias $=-0.29 \mathrm{~K}$, RMS difference $=1.14 \mathrm{~K}$ and correlation $=0.99$. Second panels: Zonal mean temperature anomaly with respect to Levitus climatology. Third panels: Tropical Pacific surface currents. Bottom panels: salinity anomaly at $190 \mathrm{~m}$ in vicinity of Amazon with respect to Levitus climatology. 
sea ice is also found to be less extensive and thinner than HadGEM1 when pre-industrial control runs are compared, but the differences are greater.

The changes made to the sea ice albedo parameterisation were found to have no significant impact on the total ice area and volume in a sensitivity experiment using the HadGEM1 control run. The other sea ice improvements (detailed in Appendix A, Table A4) had no major impact on the sea ice simulation but did remove the problem of unrealistically thick ice continuously growing at certain coastal points in the Arctic (as described in McLaren et al., 2006). Therefore any differences in the sea ice between HadGEM1 and the HadGEM2-AO control run are due to changes in the atmospheric and oceanic forcing.

It should be noted that, as stated in Sect. 4.2, the HadGEM2-AO model run analysed here is a present day control run as no historically-forced transient run is available at the time of writing. As there have been major observed changes to the Arctic sea ice during the present day period (e.g. Stroeve et al., 2011), it is possible that the present day model sea ice could be different in a historical transient run compared to a control run. This could affect the present day comparisons made here with observations and the historical HadGEM1 run, but unfortunately this is unavoidable.

\subsubsection{Ocean}

A key motivation for targeting tropical performance in the HadGEM2 family was to improve the simulation of ENSO over that in HadGEM1. The changes to the tropospheric component implemented in HadGEM2-AO (see Sect. 4.2.1) resulted in substantial improvement in the equatorial near surface winds compared with HadGEM1, as well as significantly reducing the mean global SST biases. A significant difference between the ocean components of HadGEM1 and HadGEM2 is the reduction of the background vertical tracer diffusivity from $10^{-5} \mathrm{~m}^{2} \mathrm{~s}^{-1}$ to $10^{-6} \mathrm{~m}^{2} \mathrm{~s}^{-1}$ in the upper $500 \mathrm{~m}$ of the ocean. This change was introduced to reduce the sea surface temperature cool bias, by inhibiting the mixing of cooler water from below. Figure 12 (top panels) shows mean sea surface temperature anomalies for HadGEM1 and HadGEM2-AO. It is clear that the reduction in background tracer diffusivity has had the desired effect, as it reduces the global mean SST bias from $-0.7 \mathrm{~K}$ to $-0.3 \mathrm{~K}$.

Together, we would expect these changes to have a positive impact on the mean state of the equatorial Pacific and the simulation of ENSO in the model, and many improvements compared with observations were seen in the ENSO metrics described by Martin et al. (2010). Although ENSO amplitudes and periods can vary appreciably over multiple decades (e.g. Wittenberg, 2009), the values quoted by Martin et al. (2010) were calculated over more than $150 \mathrm{yr}$ of model run and can therefore be considered robust. Despite these improvements, the frequency of large El Niño events (the average period for events $>1.5$ standard deviation) is reduced

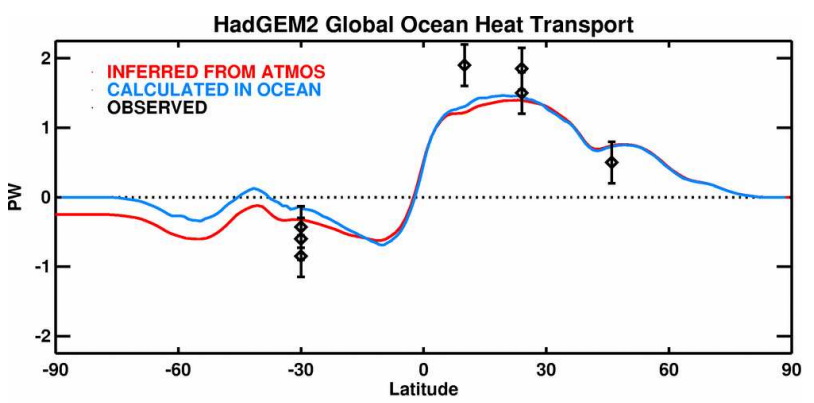

HadGEM2 Global Ocean Freshwater Transport

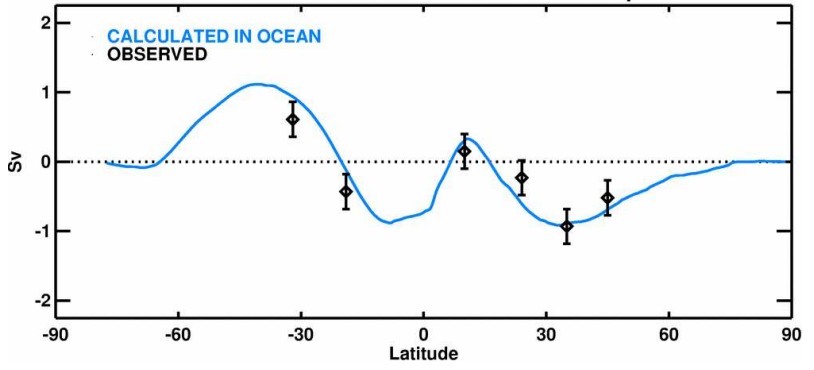

Fig. 13. Heat (top) and freshwater (bottom) transports in HadGEM2-AO global ocean, compared with observations (see Bryden and Imawaki, 2001; Wijffels, 2001).

in HadGEM2-AO compared with both HadGEM1 and observations (Martin et al., 2010, their Table 3) and a power spectrum analysis reveals a weak signal at the observed timescale ( $\sim 4 \mathrm{yr}$ ), noticeable power at $6-7 \mathrm{yr}$ and a dominant peak on decadal timescales (Collins et al., 2008, their Fig. 2.5). Martin et al. (2010) discuss possible reasons for this, which include poor simulation of the ENSO phase-changing process in HadGEM2-AO. An improvement in the capability of models to simulate the change of phase of ENSO will be a target for future configurations at all resolutions.

The drawback to the change to ocean background vertical tracer diffusivity is that the surface cooling has been shifted down the water column, so that there is now significant cooling at depth, as is clear from the corresponding zonal mean ocean temperature anomalies shown in Fig. 12 (second panels). HadGEM2-AO is over $3 \mathrm{~K}$ cooler than climatology in the zonal mean temperature at some depths.

Another change effected in the transition from HadGEM1 to HadGEM2 is a reduction in the Laplacian viscosity everywhere, but especially in the tropics, from a constant value of $2000 \mathrm{~m}^{2} \mathrm{~s}^{-1}$ to $1500 \sin ^{2}(\phi / 2) \mathrm{m}^{2} \mathrm{~s}^{-1}$, where $\phi$ is the latitude. The additional HadGEM1 bi-Laplacian viscosity of $10^{13} \cos ^{3} \phi \mathrm{m}^{4} \mathrm{~s}^{-1}$ is retained. The aim of this change is to increase the strength of the equatorial undercurrent and therefore reduce the strength of the equatorial surface westward currents in the tropical Pacific (Roberts et al., 2009), They should then be closer to the observations, (e.g. Ocean Surface Current Analyses - Realtime (OSCAR) observations; Johnson et al., 2007), which show a minimum in the 

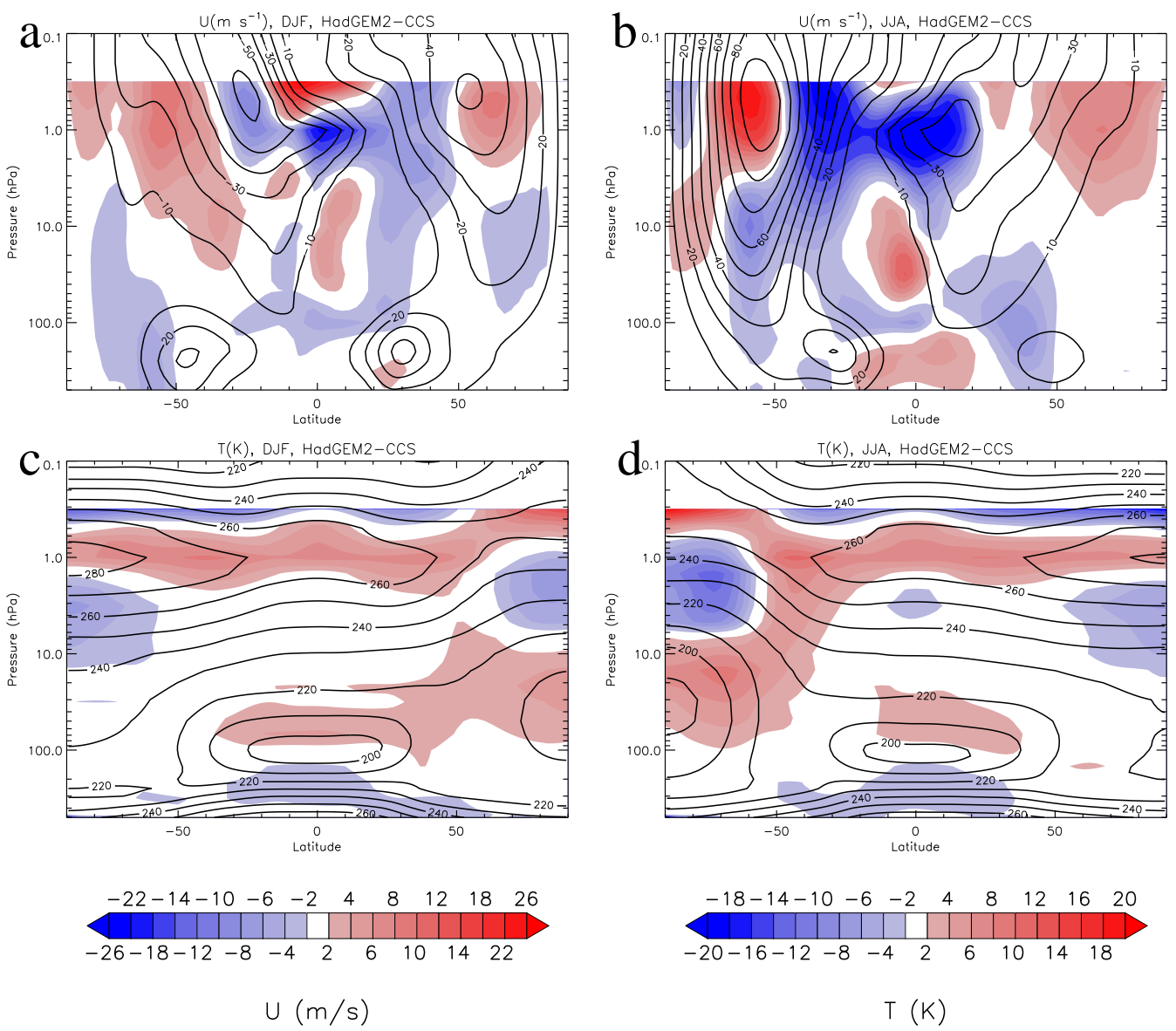

Fig. 14. Zonal mean zonal wind (U) and temperature (T) climatologies for DJF and JJA from HadGEM2-CCS, averaged 1980-2002 (black lines). Red/blue regions show a warm/cold bias with respect to UK Met Office analyses (averaged 1992-2001, the exact years used are found not to matter) with shading interval $2 \mathrm{~m} \mathrm{~s}^{-1}$ (in $\mathrm{U}$ plots) or $2 \mathrm{~K}$ (in $T$ plots).

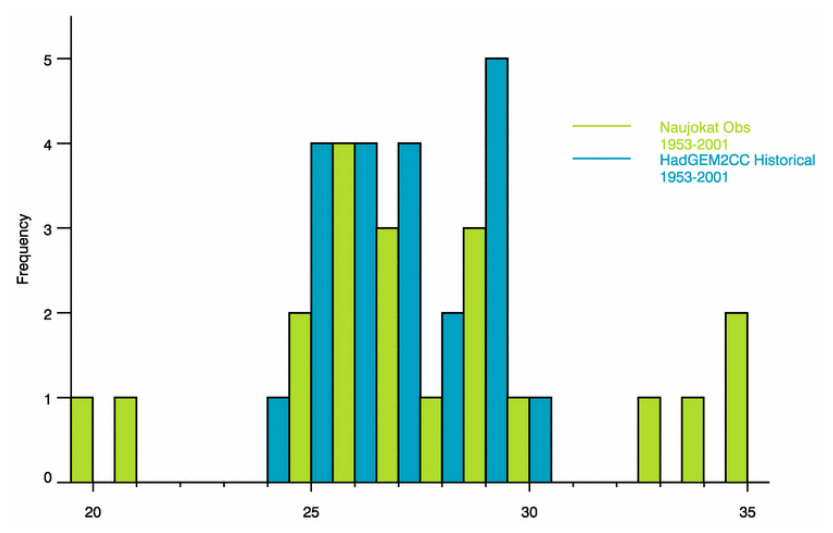

Fig. 15. Frequency of QBO periods for HadGEM2-CCS and Naujokat observations (Marquardt and Naujokat, 1997).

annual mean zonal current on the equator. Figure 12 (third panels) shows the ocean currents at $15 \mathrm{~m}$ in HadGEM1 and HadGEM2-AO. The westward flow on the equator is clearly reduced by the reduction of the Laplacian viscosity in the tropics. The equatorial undercurrent (not shown), is strengthened, with a peak value just greater than $100 \mathrm{~cm} \mathrm{~s}^{-1}$, which brings it closer to observations (e.g. Large et al., 2001).

The strength of the Atlantic Meridional Overturning Circulation (AMOC) in HadGEM2-ES in 1990-2000 is 16.0土 $1.0 \mathrm{~Sv}$ (mean and standard deviation of annual mean overturning streamfunction minima at $30^{\circ} \mathrm{N}$ from a four-member ensemble of historical simulations; Menary et al., 2011), only slightly weaker than observational estimates of the AMOC from $26.5^{\circ} \mathrm{N}$ of $18.7 \pm 2.1 \mathrm{~Sv}$ (mean and best estimate of uncertainty over the period 2004-2008; Kanzow et al., 2010). The AMOC strength at $26^{\circ} \mathrm{N}$ in the pre-industrial control simulation of HadGEM2-ES is $13.3 \pm 1.0 \mathrm{~Sv}$ (mean and standard deviation of $495 \mathrm{yr}$ of annual mean data; Roberts and Palmer, 2011), which is rather weaker than that in the pre-industrial control simulation of HadGEM1 at the same latitude ( $16.0 \pm 1.0 \mathrm{~Sv}$ : mean and standard deviation of $1150 \mathrm{yr}$ of annual mean data; Roberts and Palmer, 2011). 
Another change between HadGEM1 and HadGEM2 is an increase in horizontal and vertical tracer diffusivity near river mouths. This was introduced to counter a known excess salinity bias near some river mouths, particularly that of the Amazon. Figure 12 (bottom panels) shows that increasing the diffusivity near the river mouths has reduced the excess salinity at around $200 \mathrm{~m}$ near the outflow of the Amazon.

As in HadGEM1, the accumulation of frozen water on the permanent ice sheets is never returned to the freshwater cycle; that is, there is no representation of icebergs calving off ice shelves. To counterbalance this sink in the global annual mean freshwater budget, a freshwater flux field is applied to the ocean to add back a flux, invariant in time, with a pattern and scaling the same as that used in HadGEM1 but recalibrated for HadGEM2-AO ${ }^{1}$. The impact of this change on the freshwater budget can be seen in the snow mass and ice sheet component in Table 2.

Finally, as a check on the overall integrity of the coupled model, Fig. 13 shows the heat and freshwater transports calculated in the ocean model (from decadal mean fields), compared with observations. The heat transport inferred from the fluxes of heat from the atmosphere and sea-ice to the ocean is also plotted. The calculated transports are acceptably close to the observational estimates.

\subsubsection{Stratosphere}

Figure $14 \mathrm{a}$ and $\mathrm{b}$ show zonal mean zonal wind, $\mathrm{U}$, in HadGEM2-CCS and biases with respect to UK Met Office analyses. The subtropical jet strengths and the polar night jet strengths in December-January-February (DJF) and JuneJuly-August (JJA) are seen to be realistic. However, a dipole of anomalies in the winter hemisphere at around $1 \mathrm{hPa}$ shows that the polar night jet does not tilt equatorwards with height as much as in the analysis (this problem is more pronounced in JJA than in DJF. In general the simulated temperature (Fig. 14c and d) is realistic. There is a slight $(2-4 \mathrm{~K})$ warm bias at the tropical tropopause (which may influence stratospheric water vapour concentrations) and a warm bias in the extratropical winter stratospheres (again, larger in JJA than in DJF) which may influence polar stratospheric cloud formation when simulating ozone interactively, but otherwise the temperature biases are small.

The inclusion of the non-orographic gravity wave scheme allows the vertically-extended model to generate internally a quasi-biennial oscillation (QBO) of the tropical zonal mean zonal wind (Scaife et al., 2000). Marshall and Scaife (2009) suggested that better representation of the QBO in the vertically-extended model may lead to improved forecasts of European winter conditions at seasonal-to-multiannual timescales. The QBO in HadGEM2-CCS has a period of 28

1 This re-calibration was applied only to HadGEM2-AO as it was considered only after the historical runs of HadGEM2-ES were well underway.

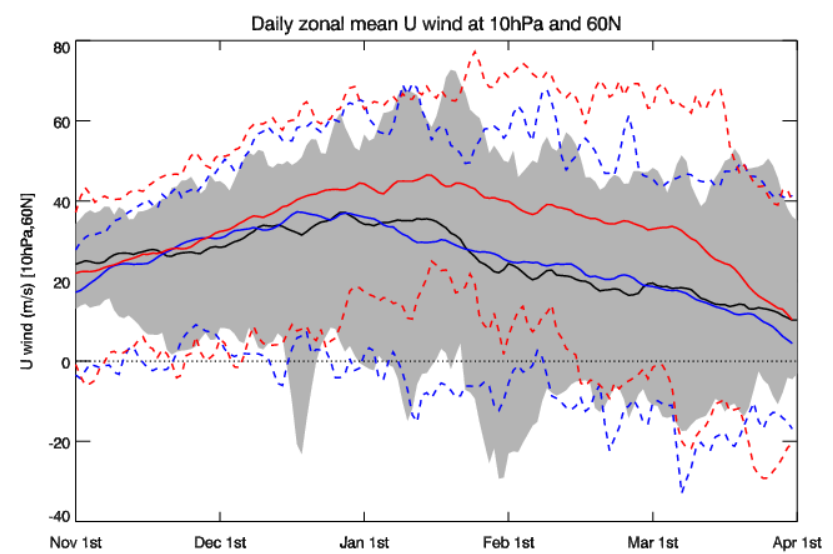

Fig. 16. Zonal mean zonal wind at $10 \mathrm{hPa}$ and $60 \mathrm{~N}$ for HadGEM2CCS (1960-2002; blue curves), HadGEM2-CC (1960-2002; red curves) and ERA-Interim reanalyses (1989-2009; black curve). Solid lines show climatological mean jet strength, dotted lines show maximum and minimum values of zonal wind, and shading shows range of values of zonal wind in ERA-Interim.

months in good agreement with observations (Baldwin et al., 2001) although Fig. 15 shows that the model does not capture the full range of periods seen in observations.

Approximately once in every two Northern-Hemisphere winters, the stratospheric polar vortex undergoes a sudden warming, defined to be a major warming if the zonal mean zonal wind at $10 \mathrm{hPa}$ and $60^{\circ} \mathrm{N}$ becomes easterly (McInturff, 1978). Marshall and Scaife (2010) used an early prototype configuration of HadGEM2-A with the same vertical extension as in HadGEM2-CCS to show that representing such sudden warmings influences the simulation of European surface winter cold spells at seasonal timescales. Figure 16 demonstrates the ability of HadGEM2-CCS to simulate these stratospheric sudden warmings. HadGEM2-CCS simulates a realistic number of major sudden warmings and shows a realistic mean jet strength. The parallel low-top version of this model, HadGEM2-CC, simulates no major sudden warmings in December-January, and only a small number of major sudden warmings (not as strong as those seen in HadGEM2CCS) in February-March. This demonstrates the need for a well resolved stratosphere to capture accurately major sudden warmings. Further, HadGEM2-CC shows a mean jet strength that is too strong, particularly in February.

The stratospheric meridional mass circulation (the Brewer-Dobson circulation) is important for the observed thermal structure of the stratosphere and essential for the transport of ozone and other chemical species throughout the stratosphere (Butchart et al., 2006). A measure of the modelled stratospheric transport is stratospheric age of air, defined here as the time since the air was last in contact with the tropospheric boundary layer. Figure 17a shows zonal mean age of air in years, averaged from $10^{\circ} \mathrm{S}$ to $10^{\circ} \mathrm{N}$, in HadGEM2-CCS and HadGEM2-CC, compared 

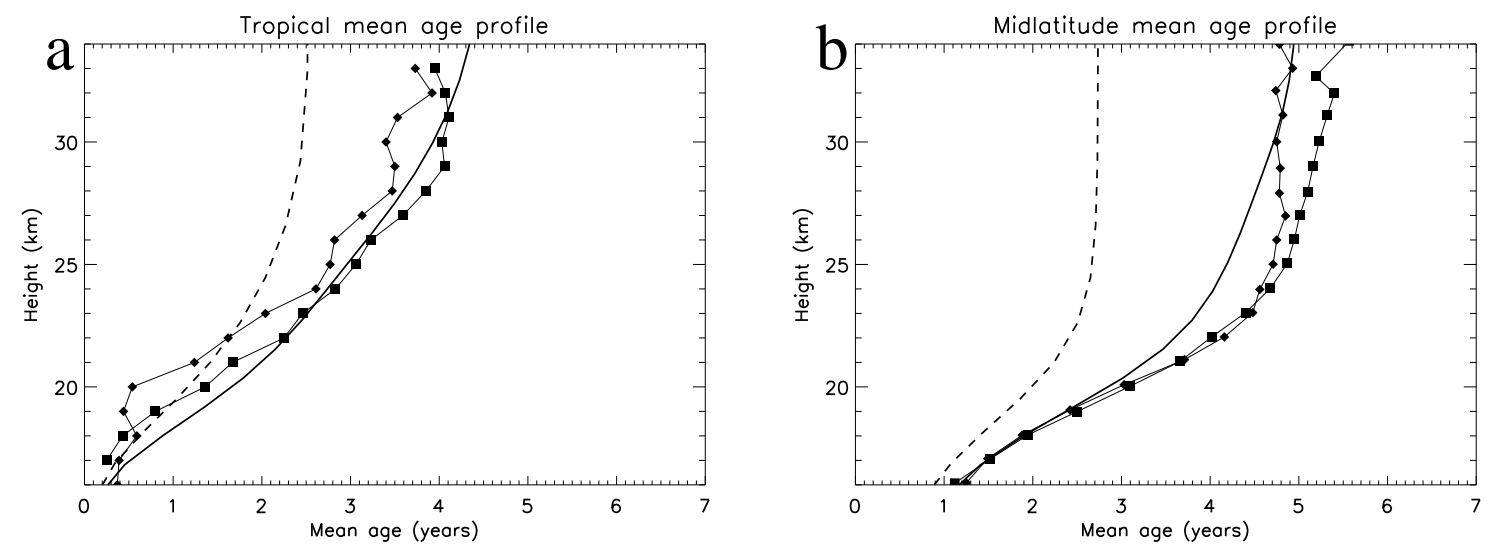

Fig. 17. Age of air (years) for HadGEM2-CCS (solid line) and HadGEM2-CC (dashed line), compared with age derived from SF 6 data $^{-}$ (squares) and $\mathrm{CO}_{2}$ data (diamonds) (Andrews et al., 2001; Engel et al., 2009): (a) Averaged from $10^{\circ} \mathrm{S}$ to $10^{\circ} \mathrm{N}$; (b) Averaged from $35^{\circ} \mathrm{N}$ to $45^{\circ} \mathrm{N}$.

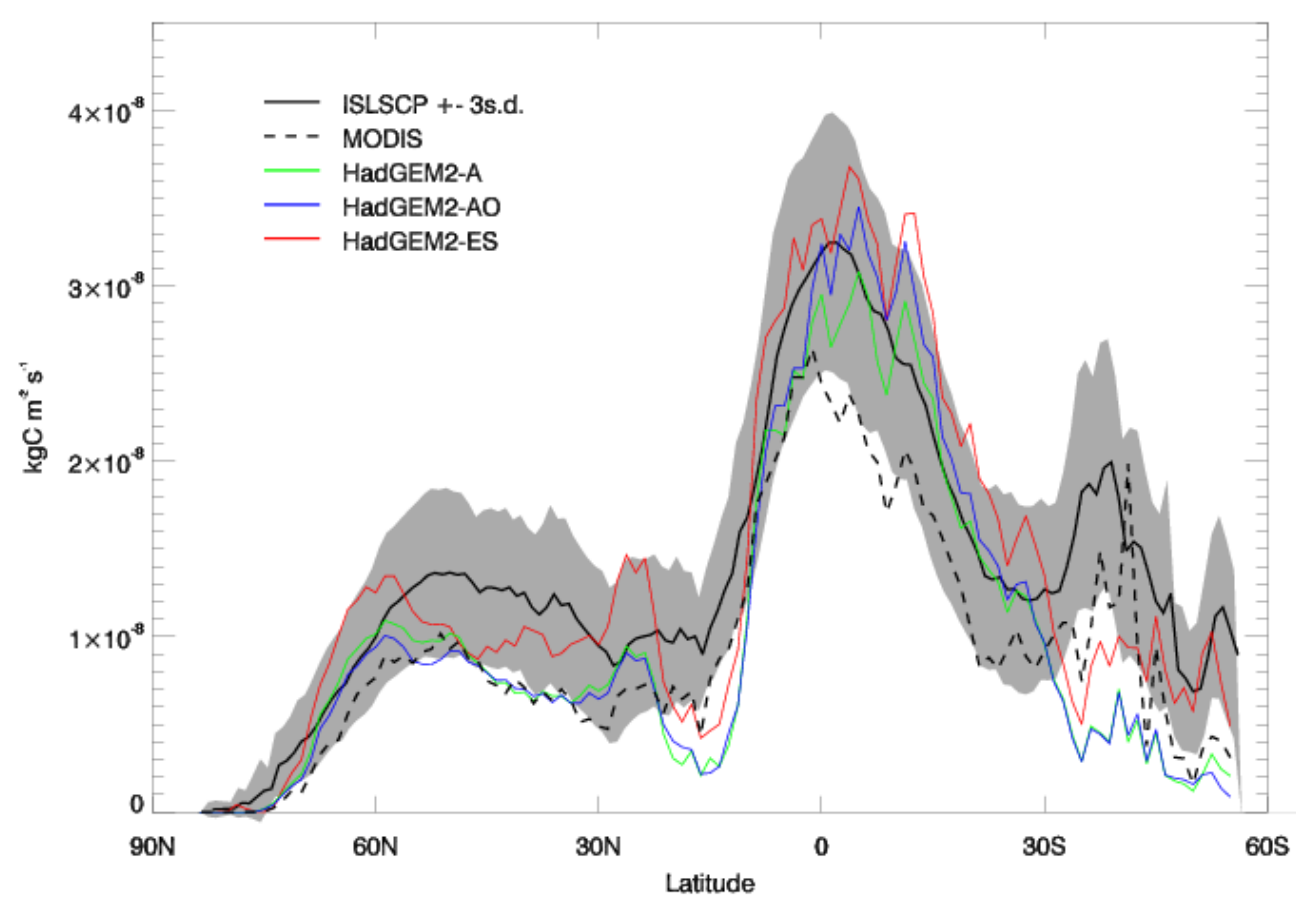

Fig. 18. Zonal mean distribution of NPP from 3 model configurations (HadGEM2-A with fixed vegetation in green, HadGEM2-AO with fixed vegetation in blue and HadGEM2-ES with dynamic vegetation in red) compared with an estimate of global NPP from the ISLSCP model database (Cramer et al., 1999; black solid) and MODIS NPP (Heinsch et al., 2003; black dashed). The ISLSCP dataset also provides the standard deviation of model results about the mean, and a comparison of the dataset with site level observations shows that \pm 3 standard deviations (shaded) is an appropriate estimate of uncertainty. MODIS NPP is systematically lower than ISLSCP estimates and coincides closely in the zonal mean with ISLSCP-3 3 . We do not fully know the reason for this difference but it highlights the large uncertainty involved in measuring vegetation productivity (Heinsch et al., 2006). Note that component carbon fluxes such as NPP are hard to measure directly; to process satellite-observed radiances into estimates of NPP requires complex algorithms (Zhao et al., 2005) and is subject to errors in the same way as estimates from land-surface models and so neither of these global climatologies can be regarded as true observations of NPP. 
(a) NPP: -AO minus -A

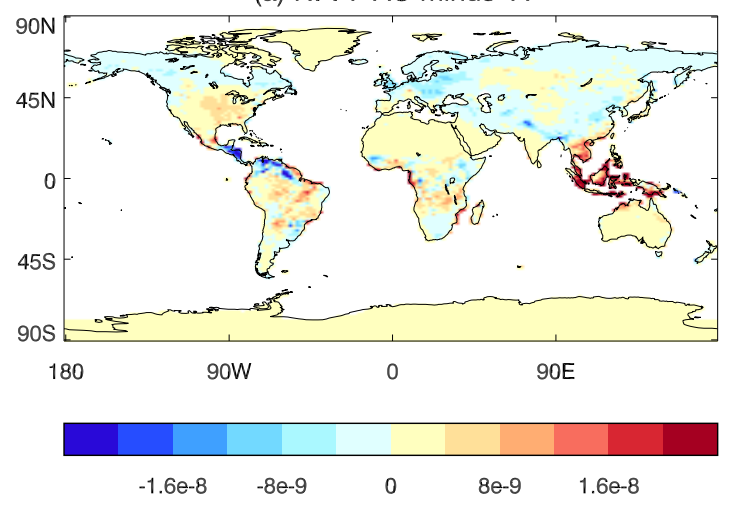

(c) NPP: -ES minus -ES scaled

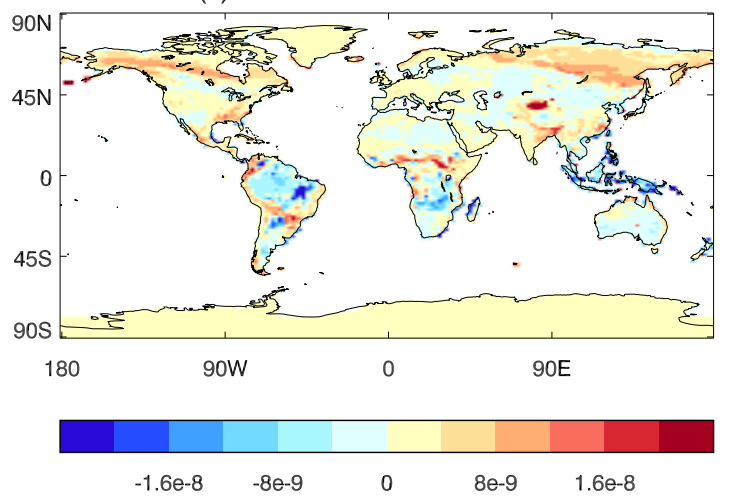

(b) NPP: -ES minus -AO

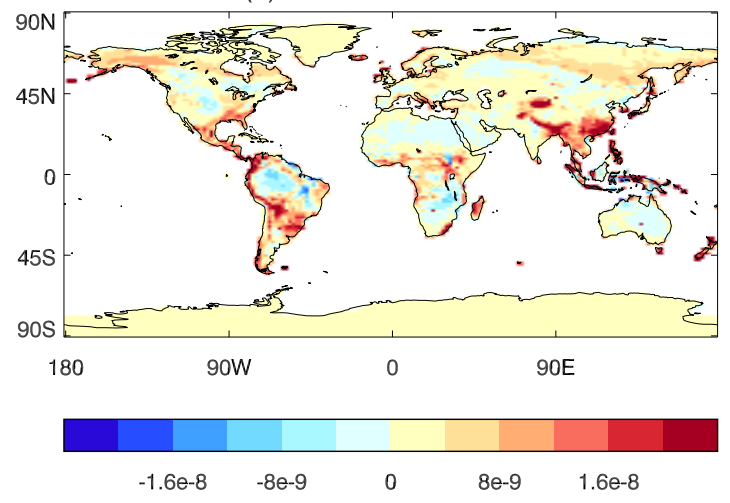

(d) NPP: -AO minus -ES scaled

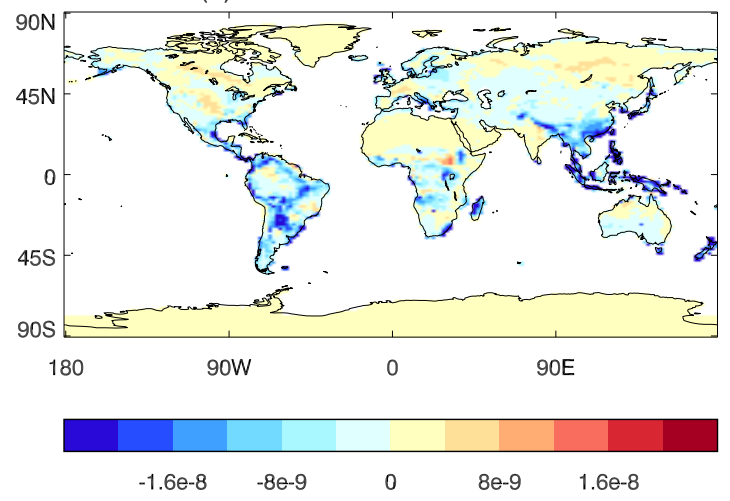

Fig. 19. Geographical distribution of NPP differences between 3 model configurations (HadGEM2-A with fixed vegetation, HadGEM2AO with fixed vegetation and HadGEM2-ES with dynamic vegetation). A re-scaled distribution from HadGEM2-ES is also shown to take account of the difference in surface vegetation cover in that model.

with observations, while Fig. 17b shows the same but with age of air averaged from $35^{\circ} \mathrm{N}$ to $45^{\circ} \mathrm{N}$. Age at both of these latitude bands is too young in HadGEM2-CC, but age is more realistic in HadGEM2-CCS showing that a well resolved stratosphere is essential to simulate realistic stratospheric transport.

\subsubsection{Terrestrial carbon cycle}

In this section we analyse the simulation of the terrestrial carbon cycle in HadGEM2 family members under present day climate and carbon dioxide conditions. Although the carbon cycle component is included in HadGEM2-CC, HadGEM2CCS and HadGEM2-ES, the terrestrial carbon cycle was found to be similar in these configurations (indicating that the inclusion of tropospheric chemistry in HadGEM2-ES has little impact on this aspect of the simulation), so results shown here are limited to those from HadGEM2-ES.

The earth system components are shown to perform well. Vegetation cover, soil respiration and carbon storage are simulated in HadGEM2-ES, -CC and -CCS only, whereas vegetation cover is prescribed in HadGEM2-A and - AO. In HadGEM2-ES, -CC and -CCS, through rigorous reevaluation of the vegetation parameters, the vegetation cover is now significantly better than in a previous generation Met Office Hadley Centre model (HadCM3LC) in which the TRIFFID vegetation scheme was also used, although the presence of too much bare soil in some semi-arid and arid regions causes problems for the dust emissions scheme (see Sect. 4.2.3). The simulation of global soil and biomass carbon stores are good and agree well with observed estimates and with the Coupled Climate Carbon Cycle Model Intercomparison Project (C4MIP) ensemble of models (Friedlingstein et al., 2006). See Collins et al. (2011) for more details.

HadGEM2 simulates NPP for each of 5 plant functional types (PFTs: broadleaf tree, needleleaf tree, C3 and C4 grass and shrub) regardless of whether dynamic vegetation is enabled or not. When dynamic vegetation is enabled (in HadGEM2-ES and HadGEM2-CC) NPP contributes to the accumulated carbon balance which determines the competition between PFTs. Figure 18 shows the zonal distribution of global NPP from several HadGEM2 configurations (-A, -AO 


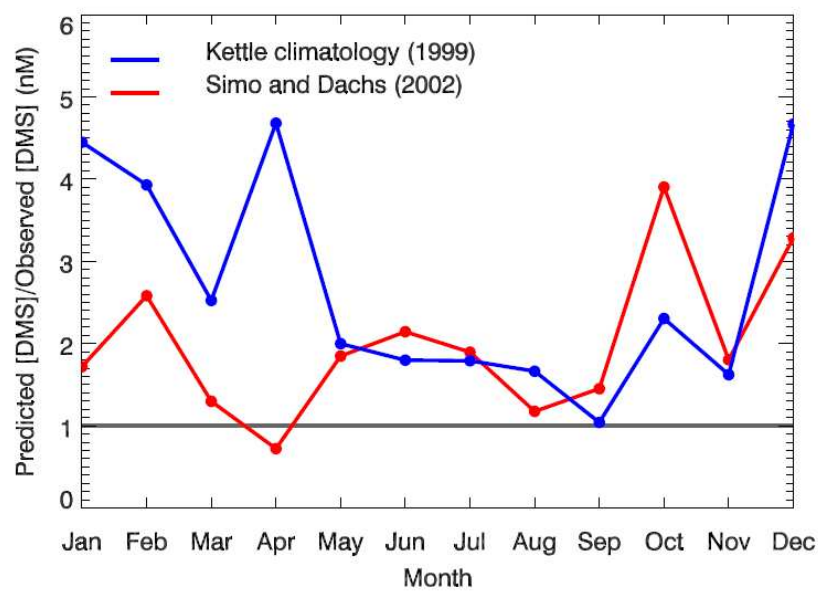

Fig. 20. Surface ocean DMS concentrations; comparison of HadGEM2 (using an adaptation of the Simo and Dachs scheme) and the Kettle et al. (1999) climatology scaled by observations from http://saga.pmel.noaa.gov/dms/, considering only sites where observations independent from those used to develop the climatology and parameterisation were present.

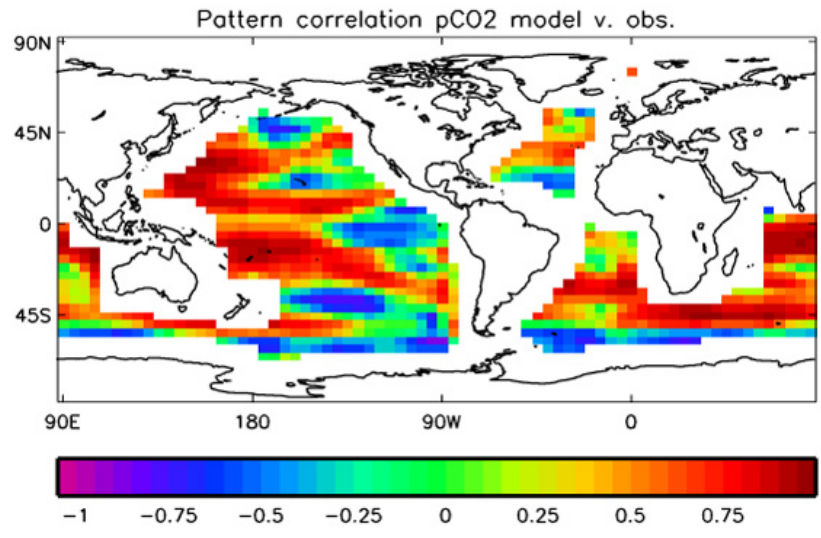

Fig. 21. Pattern correlation between the modelled ocean surface partial pressure of $\mathrm{CO}_{2}$ and observation-based climatology produced by Takahashi et al. (2009). Values were calculated for each model point by correlating the pattern in the $5 \times 5$ grid cells surrounding that point with the corresponding $5 \times 5$ grid cells in the climatology. Where any of the $5 \times 5$ grid-cell region fell over land, no correlation was calculated.

and -ES) compared with climatologies from the ISLSCP ${ }^{2}$ model-mean dataset and the Moderate Resolution Imaging Spectroradiometer (MODIS; Heinsch et al., 2003). The comparison shows that HadGEM2-ES simulates greater productivity than HadGEM2-AO, and HadGEM2-AO greater than HadGEM2-A. Generally, all model configurations perform

2 The International Satellite Land Surface Climatology Project (Cramer et al., 1999) which is derived from the mean NPP simulations of 17 terrestrial ecosystem models driven by observed climate.

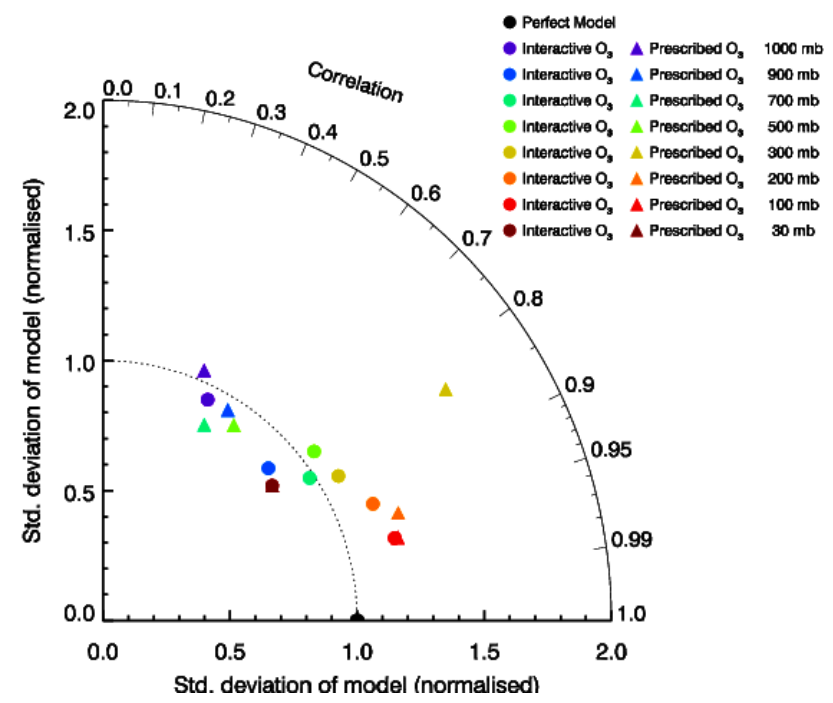

Fig. 22. Taylor Diagram comparing modelled (circles) and prescribed (triangles) ozone with climatological observations from Logan (1999) at a number of pressure levels, using over 40 worldwide sites and all monthly output.

well in the tropics, whereas -ES is better in temperate and northern latitudes where -A and -AO are too low. Figure 19 shows the geographical distribution of the differences between these configurations. Figure 19a shows that the -AO and -A configurations are very similar outside the tropics. Within the tropics the difference is dominated by higher NPP in the -AO configuration over the maritime continent. In this region there is a known tendency for coupled models to simulate significantly more precipitation than atmosphere only models due to a feedback between biases in convective activity and sea surface temperatures (Martin et al., 2006; Inness and Slingo, 2003).

Both Figs. 18 and 19b show that the -ES configuration simulates greater NPP than the -AO configuration across all latitudes. The two possible causes for this are differences in simulated vegetation cover or differences in simulated surface climate. Because NPP is simulated for each PFT it is possible to reconstruct what the total NPP distribution from a simulation would be with a different vegetation distribution. Figure 19c shows the difference between the -ES NPP and that which the -ES land-surface would produce given the IGBP climatological vegetation distribution as prescribed for the -AO simulation. The spatial distribution of the difference is similar, indicating that at least some of the difference is due to differences in the vegetation simulation, but the differences are generally smaller in magnitude than the -ES vs -AO difference. Figure 19d shows the differences between this re-scaled -ES NPP and the -AO configuration. In the extra-tropics these differences are small, indicating that most of the extra-tropical NPP difference between -ES and $-\mathrm{AO}$ configurations is due to differences in simulated 
vegetation state. In particular, the -ES model simulates a relatively poor distribution of boreal forest in east Asia and Siberia, as discussed in Collins et al. (2011). However, in the tropics, the re-scaled -ES NPP is systematically greater than the -AO NPP distribution, implying that differences in climate between -AO and -ES are the key driver of NPP differences here. Collins et al. (2011) show differences in surface temperature and precipitation between HadGEM2 configurations with prescribed or simulated vegetation cover. Across the tropics, the simulated vegetation cover generally has too great an extent of tropical forest and is systematically cooler than with prescribed vegetation. This may explain the observed -ES and -AO differences in tropical NPP.

\subsubsection{Ocean biogeochemistry}

The ocean biology (diat-HadOCC) allows the completion of the carbon cycle and the provision of di-methyl sulphide (DMS) emissions from phytoplankton. DMS is a significant source of sulphate aerosol over the oceans and is parameterised in diat-HadOCC using an adaptation of the scheme proposed by Simo and Dachs (2002). This scheme is fully described and validated in Halloran et al. (2010).

The diat-HadOCC scheme is an improvement over the standard HadOCC scheme as it differentiates between diatom and non-diatom plankton. These have different processes for removing carbon, and in the case of the nondiatom functional type, alkalinity, from the surface to the deep ocean, and respond differently to iron and silica availability. The diat-HadOCC scheme performs well with very reasonable plankton distributions, rates of productivity and emissions of DMS.

In HadGEM1 the sulphate aerosol scheme was driven by DMS surface ocean concentrations provided by a climatology from Kettle et al. (1999). Figure 20 shows that the interactive DMS scheme compares much better with observations than does the climatology.

Figure 21 shows the correlation between the surface ocean $\mathrm{CO}_{2}$ concentrations simulated by diat-HadOCC and observations by Takahashi et al. (2009). The large red areas show good correlations, although there are some poorer areas (coloured blue). Further discussion of the ocean biogeochemistry component of HadGEM2 can be found in Collins et al. $(2008,2011)$.

\subsubsection{Tropospheric chemistry}

The additions of a tropospheric chemistry scheme, new aerosol species (organic carbon and dust) and coupling between the chemistry and sulphate aerosols have significantly enhanced the earth system capabilities of the model. This has improved the tropospheric ozone distribution and the distributions of aerosol species compared to observations, both of which are important for climate forcing.
An assessment is plotted as a Taylor diagram in Fig. 22, where interactively modelled and prescribed (Jones et al., 2011) ozone concentrations are compared with the climatological observations at a number of different pressure levels. The global performance of modelled ozone from the UKCA interactive chemistry is improved compared with the prescribed ozone concentrations at several pressure levels. From $3 \mathrm{~km}$ above the tropopause, the interactive ozone values are relaxed to the CMIP5 climatology (Collins et al., 2011). The ozone concentrations near the tropical tropopause are higher in the prescribed distribution due to a lower ozone tropopause in HadGEM2-ES (diagnosed from the $150 \mathrm{ppb}$ contour; Collins et al., 2011). This has implications for temperatures in the tropical tropopause region (O'Connor et al., 2009). Further discussion of the impacts of the tropospheric chemistry component on HadGEM2-ES can be found in Collins et al. (2008, 2011).

\section{Summary}

The HadGEM2 family of models represents the state-of-theart in global coupled modelling. The strategy of creating a model "family" was introduced in order to allow a traceable set of model configurations which incorporate different levels of complexity but have a common physical framework. This approach has several benefits for climate change modelling, including the use of models with common processes for a wide range of science questions. The computational cost of running full Earth-System models for all applications is likely to be prohibitive in the foreseeable future, and the additional feedbacks from more interactive components of ES models will increase the uncertainty in the magnitude and nature of the climate changes projected in future scenario simulations (Hurrell et al., 2009). Using a traceable hierarchy of models of varying complexity will help us to explore the physical mechanisms of climate change on a range of timescales. Certain components may not be required for shorter timescales (e.g. decadal predictions), which may allow such predictions to be made using higher resolution models.

Including interactive earth system components has not significantly affected the large-scale physical performance of the model. This provides assurance of consistency within our set of model configurations. The physical model shows improvements over the previous version, HadGEM1, particularly in the tropics, which were targeted for improvement through a seamless modelling strategy (Martin et al., 2010). Issues remain with deep ocean temperatures and ENSO variability. The MetUM is currently moving to a new coupled modelling system including the NEMO (Madec, 2008) ocean and CICE (Hunke and Lipscomb, 2008) sea ice components, as well as updated physical parametrisations and increased vertical resolution in both atmosphere and ocean (see Hewitt 
Table A1. Troposphere - based on HadGEM1 with improvements to convection and boundary layer schemes plus assorted corrections.

\begin{tabular}{|c|c|c|c|}
\hline & Change & Reason for change & References \\
\hline r1.0 & $\begin{array}{l}\text { Inclusion of "adaptive detrainment" } \\
\text { parametrization }\end{array}$ & $\begin{array}{l}\text { Produces smoother mass-flux } \\
\text { profiles and more realistic } \\
\text { diabatic heating profiles. }\end{array}$ & Derbyshire et al. (2011) \\
\hline r1.0 & $\begin{array}{l}\text { Exponential decay of convective cloud } \\
\text { seen by radiation scheme with } 2 \text {-h half } \\
\text { life }\end{array}$ & $\begin{array}{l}\text { To compensate for intermittent } \\
\text { triggering of convection and the } \\
\text { 3-h calling of radiation scheme }\end{array}$ & Martin et al. (2010) \\
\hline r1.0 & $\begin{array}{l}\text { Depth criterion for shallow convection } \\
\text { removed }\end{array}$ & $\begin{array}{l}\text { To allow shallower clouds to rain } \\
\text { provided their water content } \\
\text { is sufficiently high. }\end{array}$ & Gregory and Rowntree (1990) \\
\hline r1.0 & $\begin{array}{l}\text { Vertical velocity threshold for targeted } \\
\text { diffusion of moisture raised from } 0.1 \text { to } \\
0.3 \mathrm{~m} \mathrm{~s}^{-1}\end{array}$ & $\begin{array}{l}\text { Targeted diffusion of moisture is } \\
\text { used to limit grid-scale convection. } \\
\text { Raising the vertical velocity } \\
\text { threshold limits the application of } \\
\text { this diffusion to only those points } \\
\text { which are in danger of going } \\
\text { numerically unstable. }\end{array}$ & Shaffrey et al. (2009) \\
\hline r1.0 & Non-gradient stress parametrisation & $\begin{array}{l}\text { Generates improved (more well } \\
\text {-mixed) wind profiles in convective } \\
\text { boundary layers. }\end{array}$ & Brown and Grant (1997) \\
\hline r1.0 & $\begin{array}{l}\text { Allow for salinity in evaporation of sea } \\
\text { water }\end{array}$ & $\begin{array}{l}\text { More accurate moisture fluxes over } \\
\text { the ocean }\end{array}$ & \\
\hline r1.0 & $\begin{array}{l}\text { Changes to the surface scalar transport } \\
\text { over the ocean }\end{array}$ & $\begin{array}{l}\text { Brings dependence on wind speed } \\
\text { more in line with observations }\end{array}$ & $\begin{array}{l}\text { Edwards (2007) } \\
\text { Brown et al. (2008) }\end{array}$ \\
\hline r1.1 & $\begin{array}{l}\text { Correction to Rayleigh scattering } \\
\text { coefficients }\end{array}$ & $\begin{array}{l}\text { Coefficients found to have been } \\
\text { calculated incorrectly in previous } \\
\text { model versions. }\end{array}$ & \\
\hline r1.1 & Use Randel and Wu (2007) dataset & $\begin{array}{l}\text { Improved ozone trends and updated } \\
\text { with recent observations }\end{array}$ & Randel and Wu (2007) \\
\hline
\end{tabular}

et al., 2011). It is hoped that these changes will result in further reductions in model systematic errors.

The earth system components of HadGEM2-ES compare well with observations and with other models. In addition, stratospheric processes and variability are represented realistically in the vertically-extended model configuration. Therefore we can conclude that the HadGEM2 family of models is a valuable tool for predicting future climate and understanding the climate feedbacks within the earth system. HadGEM2-ES will be used to perform the Met Office Hadley Centre's contribution to the CMIP5 modelling activity for Intergovernmental Panel on Climate Change (IPCC) 5th Assessment Report (Jones et al., 2011).

\section{Appendix A}

\section{Science changes between HadGEM1 and HadGEM2}

Tables A1 to A9 summarise the changes made between HadGEM1 and HadGEM2, and the additional processes represented in the HadGEM2 model family, The first release (r1.0; Johns et al., 2011) of the Troposphere, Aerosols, Land Surface \& Hydrology and Ocean \& Sea-ice components has been used in the European project, ENSEMBLES, an ensemble prediction system for climate change based on the principal state-of-the-art, high resolution, global and regional Earth System models developed in Europe (see http: //ensembles-eu.metoffice.com). The second release (r1.1) of these components includes all changes made in r1.0 plus several additional modifications. The Stratosphere, Terrestrial Carbon Cycle, Ocean Biogeochemistry and Tropospheric Chemistry components are only available at r1.1. Configurations created from the r1.1 release are used to create 
Table A2. Land Surface and Hydrology - based on HadGEM1 with changes to surface runoff from saturated soils, surface albedo and emissivity, plus new canopy radiation and hydrology schemes.

\begin{tabular}{|c|c|c|c|}
\hline & Change & Reason for change & References \\
\hline r1.0 & $\begin{array}{l}\text { Excess soil water (e.g. through } \\
\text { snowmelt) drained out of the bottom } \\
\text { of the soil layer instead of being pushed } \\
\text { back out of the top layer }\end{array}$ & $\begin{array}{l}\text { Increases soil moisture in lower } \\
\text { soil layers and so helps to reduce } \\
\text { water-stress on vegetation following } \\
\text { snowmelt in northern hemispheric } \\
\text { continents. }\end{array}$ & $\begin{array}{l}\text { Similar to MOSES I } \\
\text { (Cox et al., 1999) }\end{array}$ \\
\hline r1.0 & Correction to soil hydraulic properties & $\begin{array}{l}\text { Corrects implementation of Cosby et } \\
\text { al. (1984) equations. }\end{array}$ & Dharssi et al. (2009) \\
\hline r1.0 & $\begin{array}{l}\text { Change soil dataset from Wilson and } \\
\text { Henderson-Sellers (1985) to the } \\
\text { International Geophysical Biophysical } \\
\text { Programme Data and Information } \\
\text { System (IGBP-DIS; Global Soil Data } \\
\text { Task Group, 2000). The soil hydraulic } \\
\text { scheme is that of Clapp and Hornberger } \\
\text { (1978), as in HadGEM1. }\end{array}$ & $\begin{array}{l}\text { The soil properties (sand/silt/clay } \\
\text { fractions) were updated in order to } \\
\text { improve soil moisture and thence } \\
\text { dust distributions in the Saharan } \\
\text { region. }\end{array}$ & Woodward (2011) \\
\hline $\mathrm{r} 1.0$ & $\begin{array}{l}\text { Two-stream multi-layer canopy } \\
\text { radiation scheme }\end{array}$ & $\begin{array}{l}\text { Allows both decreasing leaf nitrogen } \\
\text { with height and light inhibition leaf } \\
\text { respiration. Improves simulation of the } \\
\text { diurnal cycle of surface fluxes. }\end{array}$ & Jogireddy et al. (2006) \\
\hline r1.1 & $\begin{array}{l}\text { Improvements/corrections to coupling } \\
\text { between river routing scheme (TRIP; } \\
\text { Oki and Sud 1998; Falloon and Betts, } \\
\text { 2006) and land surface model to ensure } \\
\text { proper transfer of runoff fluxes and } \\
\text { integrated river flows into the ocean. }\end{array}$ & $\begin{array}{l}\text { Errors in the formulation of coupling } \\
\text { between river routing scheme and land } \\
\text { surface model led to a lack of water } \\
\text { conservation in HadGEM1. }\end{array}$ & Johns et al. (2006) \\
\hline r1.1 & $\begin{array}{l}\text { River water is now added to the soil } \\
\text { moisture at the location of the inland } \\
\text { basin until this grid point becomes } \\
\text { saturated. For saturated basins, water } \\
\text { conservation is forced to be maintained } \\
\text { by scaling the total coastal outflow. }\end{array}$ & $\begin{array}{l}\text { Runoff draining into inland basins was } \\
\text { previously lost to the system. }\end{array}$ & Johns et al. (2006) \\
\hline r1.1 & New soil and vegetation albedos & $\begin{array}{l}\text { New values derived from the Moderate } \\
\text { Resolution Imaging Spectroradiometer } \\
\text { (MODIS). }\end{array}$ & Houldcroft et al. (2009) \\
\hline $\mathrm{r} 1.1$ & Include land surface hydrology scheme & $\begin{array}{l}\text { To allow sub-gridscale soil moisture } \\
\text { variability, improving soil moisture } \\
\text { distribution. }\end{array}$ & Clark and Gedney (2008) \\
\hline r1.1 & $\begin{array}{l}\text { Allow lake evaporation to deplete soil } \\
\text { moisture. The global lake evaporation } \\
\text { flux is calculated and removed evenly } \\
\text { from the soil moisture over the whole } \\
\text { land surface }\end{array}$ & $\begin{array}{l}\text { Lakes in the Met Office Surface } \\
\text { Exchange Scheme version } 2 \text { (MOSES- } \\
\text { II; Essery et al., 2003) are not modelled } \\
\text { interactively, but have a fixed extent. In } \\
\text { HadGEM1, evaporation from lakes was } \\
\text { therefore a net source of water into the } \\
\text { climate system. }\end{array}$ & \\
\hline $\mathrm{r} 1.1$ & $\begin{array}{l}\text { Land ice, snow on vegetation, and } \\
\text { ocean albedo all reduced by } 5 \%\end{array}$ & $\begin{array}{l}\text { Calibration within acceptable } \\
\text { parameter range, to achieve closer } \\
\text { top-of-atmosphere radiative balance. }\end{array}$ & \\
\hline r1.1 & $\begin{array}{l}\text { Land surface emissivity reduced from } \\
1.0 \text { to } 0.97\end{array}$ & $\begin{array}{l}\text { Better agreement with observations. } \\
\text { Changed to achieve closer top-of- } \\
\text { atmosphere radiative balance. }\end{array}$ & \\
\hline
\end{tabular}


Table A3. Aerosols - based on HadGEM1 plus additional aerosol species and with changes to the interaction with radiation.

\begin{tabular}{|c|c|c|c|}
\hline & Change & Reason for change & References \\
\hline $\mathrm{r} 1.0$ & $\begin{array}{l}\text { Most sulphate mass now lies in } \\
\text { optically-efficient accumulation mode; } \\
\text { biomass burning aerosols experience } \\
\text { hygroscopic growth; }\end{array}$ & $\begin{array}{l}\text { Representation of aerosols is now } \\
\text { more realistic, based on observa- } \\
\text { tions gathered from dedicated field } \\
\text { campaigns. }\end{array}$ & $\begin{array}{l}\text { Bellouin et al. (2007) } \\
\text { Haywood et al. (2003) }\end{array}$ \\
\hline $\mathrm{r} 1.0$ & Mineral dust included & Important natural aerosol species. & $\begin{array}{l}\text { Woodward (2001), } \\
\text { Woodward (2011) }\end{array}$ \\
\hline $\mathrm{r} 1.0$ & $\begin{array}{l}\text { Inclusion of a biogenic aerosol } \\
\text { climatology }\end{array}$ & $\begin{array}{l}\text { Secondary organic aerosol is the } \\
\text { product of the oxidation of biogenic } \\
\text { volatile organic compounds such as } \\
\text { terpenes emitted by vegetation. }\end{array}$ & $\begin{array}{l}\text { Bellouin et al. (2007) } \\
\text { Bellouin et al. (2011) }\end{array}$ \\
\hline r1.1 & $\begin{array}{l}\text { Representation of organic carbon } \\
\text { aerosol from fossil fuel burning }\end{array}$ & $\begin{array}{l}\text { Important anthropogenic species in } \\
\text { industrialised regions. }\end{array}$ & Collins et al. (2008) \\
\hline r1.1 & Modifications to mineral dust scheme & $\begin{array}{l}\text { Dust production is highly sensitive } \\
\text { to other model changes. }\end{array}$ & Woodward (2011) \\
\hline r1.1 & $\begin{array}{l}\text { Aqueous oxidation of dissolved } \mathrm{SO}_{2} \text { by } \\
\text { dissolved ozone to produce dissolved- } \\
\text { mode sulphate aerosol in cloud droplets }\end{array}$ & $\begin{array}{l}\text { Including this reaction improves } \\
\text { modelled sulphate concentrations } \\
\text { compared with observations. }\end{array}$ & Collins et al. (2008) \\
\hline
\end{tabular}

Table A4. Sea ice - based on HadGEM1 with improvements to sea-ice albedo, heat fluxes and sea ice dynamic coupling.

\begin{tabular}{|c|c|c|c|}
\hline & Change & Reason for change & References \\
\hline $\mathrm{r} 1.0$ & $\begin{array}{l}\text { Bare sea ice albedo increased from } 0.57 \\
\text { to } 0.61 \text {; correction to sea-ice albedo } \\
\text { during surface melt }\end{array}$ & $\begin{array}{l}\text { Correction to implementation of } \\
\text { the HadGEM1 albedo parameteri- } \\
\text { sation. Bare ice albedo changed } \\
\text { (within observational constraints) } \\
\text { in conjunction with correction to } \\
\text { reproduce same ice extent and } \\
\text { volume in the HadGEM1 control } \\
\text { run. }\end{array}$ & $\begin{array}{l}\text { See Curry et al. (2001) } \\
\text { and Perovich et al. (2002) } \\
\text { for albedo range. }\end{array}$ \\
\hline $\mathrm{r} 1.0$ & $\begin{array}{l}\text { Heat fluxes passed from the atmosphere } \\
\text { to the ocean/seaice model are regridded } \\
\text { taking the ice concentration into consid- } \\
\text { eration }\end{array}$ & $\begin{array}{l}\text { To reduce growth of unrealistically } \\
\text { thick sea ice at some coastal points. }\end{array}$ & $\begin{array}{l}\text { Discussed in McLaren et } \\
\text { al. (2006) }\end{array}$ \\
\hline $\mathrm{r} 1.0$ & $\begin{array}{l}\text { Sea ice velocities combined with ocean } \\
\text { currents to create "surface currents" } \\
\text { field for use in atmosphere model }\end{array}$ & Improve dynamic coupling. & \\
\hline
\end{tabular}


Table A5. Ocean - based on HadGEM1 with improvements to Laplacian viscosity, sea-ice albedo and river run-off and changes to diffusivity.

\begin{tabular}{l|lll}
\hline & Change & Reason for change & References \\
\hline r1.0 & $\begin{array}{l}\text { An anisotropic Laplacian viscosity is } \\
\text { used, which is smaller at low latitudes } \\
\text { than the constant isotropic viscosity } \\
\text { used in HadGEM1. }\end{array}$ & $\begin{array}{l}\text { Reduces westward currents on the } \\
\text { equator, giving better agreement } \\
\text { with observations. }\end{array}$ & $\begin{array}{l}\text { Large et al. (2001); } \\
\text { Roberts et al. (2009). }\end{array}$ \\
\hline r1.0 & $\begin{array}{l}\text { Background vertical diffusivity } \\
\text { has been lowered in the upper 500 m of } \\
\text { the ocean, placing it at the edge of the } \\
\text { uncertainty range }\end{array}$ & $\begin{array}{l}\text { Reduces mixing with cooler subsur- } \\
\text { face water, increasing the SSTs and } \\
\text { also the subsurface cooling in the } \\
\text { tropics. }\end{array}$ & $\begin{array}{l}\text { See Moum and Osbourne (1986) } \\
\text { for uncertainty range. }\end{array}$ \\
\hline r1.0 & $\begin{array}{l}\text { Enhanced vertical and horizontal } \\
\text { diffusion in the ocean wherever a river } \\
\text { outflow point is present }\end{array}$ & $\begin{array}{l}\text { Corrects a known systematic salty } \\
\text { bias close to the Amazon, at a depth } \\
\text { of 150 m. }\end{array}$ & \\
\hline r1.1 & $\begin{array}{l}\text { Update ocean freshwater flux field } \\
\text { (HadGEM2-AO only) }\end{array}$ & $\begin{array}{l}\text { A fixed ocean freshwater flux field } \\
\text { is applied, nominally accounting } \\
\text { for a lack of representation of }\end{array}$ & Johns et al. (2006) \\
& $\begin{array}{l}\text { iceberg calving in the model. This } \\
\text { requires updating for each new } \\
\text { model configuration as other } \\
\text { changes to the model affect the } \\
\text { freshwater budget. }\end{array}$ & \\
& & &
\end{tabular}

Table A6. Stratosphere - new component.

\begin{tabular}{|c|c|c|}
\hline Change & Reason for change & References \\
\hline $\begin{array}{l}\text { Water vapour production by } \\
\text { oxidation of methane }\end{array}$ & $\begin{array}{l}\text { To improve the modelled } \\
\text { stratospheric water vapour. This } \\
\text { mechanism is the reason why water } \\
\text { vapour mixing ratio increases with } \\
\text { height through the stratosphere. }\end{array}$ & $\begin{array}{l}\text { Untch and Simmons (1999), } \\
\text { Simmons et al. (1999) }\end{array}$ \\
\hline $\begin{array}{l}\text { Ultra-Simple spectral } \\
\text { parameterization (USSP) }\end{array}$ & $\begin{array}{l}\text { To represent the vertical transport } \\
\text { and deposition of momentum by } \\
\text { sub-grid-scale waves }\end{array}$ & Scaife et al. (2002) \\
\hline $\begin{array}{l}\text { Changes to long-wave radiation } \\
\text { spectral files for modelling the } \\
\text { stratosphere }\end{array}$ & $\begin{array}{l}\text { To increase the accuracy of cooling } \\
\text { rates in the stratosphere and } \\
\text { mesosphere by improving the treat- } \\
\text { ment } \\
\text { of radiative absorption by gases } \\
\text { across the infrared spectrum. }\end{array}$ & $\begin{array}{l}\text { Adapted from Zhong } \\
\text { and Haigh (2000) }\end{array}$ \\
\hline
\end{tabular}

Table A7. Terrestrial Carbon Cycle - new component.

\begin{tabular}{lll}
\hline Change & Reason for change & References \\
\hline TRIFFID dynamic vegetation & To model the exchange of carbon & Cox (2001) \\
scheme; & dioxide between the atmosphere & Jones et al. (2005) \\
RothC soil carbon model. & and the terrestrial biosphere and & \\
& allow climate-driven changes in & \\
& vegetation cover to influence dust & \\
& production. & \\
\hline
\end{tabular}


Table A8. Ocean Biogeochemistry - new component.

\begin{tabular}{lll}
\hline Change & Reason for change & References \\
\hline $\begin{array}{l}\text { HadOCC and Diat-HadOCC } \\
\text { ocean biology schemes added }\end{array}$ & $\begin{array}{l}\text { To model the exchange of carbon } \\
\text { dioxide between the atmosphere } \\
\text { and the oceanic biosphere }\end{array}$ & $\begin{array}{l}\text { Palmer and Totterdell (2001) } \\
\text { Totterdell and Halloran (2011) }\end{array}$ \\
\hline $\begin{array}{l}\text { DMS emission now interactively } \\
\text { generated by the ocean biology }\end{array}$ & $\begin{array}{l}\text { This important source of sulphate } \\
\text { aerosol will now vary as climate } \\
\text { change affects the plankton }\end{array}$ & Halloran et al. (2010) \\
$\begin{array}{ll}\text { Dust deposition affects plankton } \\
\text { growth }\end{array}$ & $\begin{array}{l}\text { The supply of nutrients to the } \\
\text { plankton varies with the dust } \\
\text { production. This coupling } \\
\text { also allows geo-engineering } \\
\text { experiments to be simulated. }\end{array}$ & Totterdell and Halloran (2011) \\
& & \\
\hline
\end{tabular}

Table A9. Tropospheric Chemistry - new component.

\begin{tabular}{lll}
\hline Change & Reason for change & References \\
\hline $\begin{array}{l}\text { UKCA }{ }^{3} \text { tropospheric chemistry scheme: } \\
\text { tropospheric } \mathrm{NO}_{\mathrm{x}}-\mathrm{HO}_{\mathrm{x}}-\mathrm{CH}_{4}-\mathrm{CO}, \\
\begin{array}{l}\text { non-methane hydrocarbons, large-scale } \\
\text { transport of } 26 \text { chemical tracers }\end{array}\end{array}$ & $\begin{array}{l}\text { To allow the ozone and methane } \\
\text { radiative forcing fields, and the sulphate } \\
\text { oxidant fields, to vary with meteorology } \\
\text { and emissions. }\end{array}$ & UKCA O'Connor et al. (2011) \\
\hline $\begin{array}{l}\text { The radiative effects of ozone and methane are } \\
\text { now taken from the interactive chemistry }\end{array}$ & $\begin{array}{l}\text { This allows the concentrations of these } \\
\text { species to vary with climate and to be } \\
\text { consistent with varying tropopause } \\
\text { heights. }\end{array}$ & O'Connor (2011) \\
\hline $\begin{array}{l}\text { The emissions of methane from wetlands are } \\
\text { supplied from the hydrology scheme to the } \\
\text { chemistry scheme }\end{array}$ & $\begin{array}{l}\text { The emissions and hence concentrations } \\
\text { of methane will vary as wetlands respond } \\
\text { to changing climate. }\end{array}$ & Gedney et al. (2004) \\
\hline $\begin{array}{l}\text { Sulphate oxidation scheme now takes its } \\
\text { oxidants from the interactive chemistry }\end{array}$ & $\begin{array}{l}\text { The sulphur oxidation will now be } \\
\text { affected by meteorology and emissions }\end{array}$ & Rae (2008) \\
\hline
\end{tabular}

${ }^{3}$ United Kingdom Chemistry Aerosol community model. For more information see http://www.ukca.ac.uk/wiki/index.php/UKCA.

simulations for the IPCC Fifth Assessment (see http://www. ipcc.ch/activities/activities.htm\#1 and Jones et al., 2011).

Acknowledgements. The development of the HadGEM2 family represents the work of a large number of people, to whom the HadGEM2 Development Team is indebted. This work was supported by the Joint DECC/Defra Met Office Hadley Centre Climate Programme (GA01101).

Edited by: O. Marti

\section{References}

Adler, R. F., Huffman, G. J., Chang, A., Ferraro, R., Xie, P., Janowiak, J., Rudolf, B., Schneider, U., Curtis, S., Bolvin, D., Gruber, A., Susskind, J., and Arkin, P.: The Version 2 Global Precipitation Climatology Project (GPCP) Monthly Precipitation Analysis (1979-Present), J. Hydrometeor., 4, 1147-1167, 2003.

Andrews, A. E., Boering, K. A., Daube, B. C., Wofsy, S. C., Loewenstein, M., Jost, H., Podolske, J. R., Webster, C. R., Herman, R. L., Scott, D. C., Flesch, G. J., Moyer, E. J., Elkins, J. W., Dutton, G. S., Hurst, D. F., Moore, F. L., Ray, E. A., Romashkin, P. A., and Strahan, S. E.: Mean ages of stratospheric air derived from in situ observations of $\mathrm{CO}_{2}, \mathrm{CH}_{4}$, and $\mathrm{N}_{2} \mathrm{O}$, J. Geophys. Res., 106, 32295-32314, 2001.

Baldwin, M. P., Gray, L. J., Dunkerton, T. J., Hamilton, K., Haynes, P. H., Randel, W. J., Holton, J. R., Alexander, M. J., Hirota, I., Horinouchi, T., Jones, D. B. A., Kinnersley, J. S., Marquardt, C., Sato, K., and Takahashi, M.: The Quasi-Biennial Oscillation, 
Rev. Geophys., 39, 179-229, 2001.

Bell, C. J., Gray, L. J., Charlton-Perez, A. J., Joshi, M., and Scaife, A. A.: Stratospheric communication of El Nino teleconnections to European Winter, J. Climate, 22, 4083-4096, 2009.

Bellouin, N., Boucher, O., Haywood, J., Johnson, C., Jones, A., Rae, J., and Woodward, S.: Improved representation of aerosols for HadGEM2. Hadley Centre Technical Note 73, Met Office Hadley Centre., Exeter, EX1 3PB, UK, available from http://www.metoffice.gov.uk/learning/library/publications/ science/climate-science (last access: 28 March 2011), 2007.

Bellouin, N., Rae, J., Jones, A., Johnson, C., Haywood, J., and Boucher, O.: Aerosol forcing in the CMIP5 simulations by HadGEM2-ES and the role of ammonium nitrate, J. Geophys. Res., revised, 2011.

Blackmon, M. L.: A climatological spectral study of the $500 \mathrm{mb}$ geopotential height of the northern hemisphere, J. Atmos. Sci., 33, 1607-1623, doi:10.1175/15200469(1976)033<1607:ACSSOT>2.0.CO;2, 1976.

Bodas-Salcedo, A., Ringer, M. A., and Jones, A.: Evaluation of the Surface Radiation Budget in the atmospheric component of the Hadley Centre Global Enviromental Model (HadGEM1), J. Climate, 21, 4723-4748, doi:10.1175/2008JCLI2097.1, 2008

Bosilovich, M.: NASA's Modern Era Retrospective-analysis for Research and Applications: Integrating Earth Observations, Earthzine, 26 September 2008, available at http://www.earthzine.org/ 2008/09/26/nasas-modern-era-retrospective-analysis/, 2008.

Bosilovich, M., Schubert, S. D., Kim, G., Gelaro, R., Rienecker, M., Suarez, M., and Todling, R.: NASA's Modern Era Retrospectiveanalysis for Research and Applications (MERRA), U.S. CLIVAR Var., 4, 5-8., 2006.

Bourke, R. H. and Garrett, R. P.,: Sea Ice Thickness Distribution in the Arctic Ocean, Cold Reg. Sci. Technol., 13 (1987) 259-280, 1986.

Brown, A. R. and Grant, A. L. M.: Non-local mixing of momentum in the convective boundary layer, Bound.-Lay. Meteorol., 84, 122, 1997

Brown, A. R., Beare, R. J., Edwards, J. M., Lock, A. P., Keogh, S. J., Milton, S. F., and Walters, D. N.: Upgrades to the BoundaryLayer Scheme in the Met Office Numerical Weather Prediction Model, Bound.-Lay. Meteorol., 128, 117-132, 2008

Bryden H. and Imawaki, S.: Ocean Heat Transport, Chap 6.1 of Ocean Circulation \& Climate, International Geophysics Series, 77, Academic Press, 2001.

Butchart, N., Scaife, A., Bourqui, M., de Grandpré, J., Hare, S. H. E., Kettleborough, J., Langematz, U., Manzini, E., Sassi, F., Shibata, K., Shindell, D., and Sigmond, M.: Simulations of anthropogenic change in the strength of the Brewer-Dobson circulation, Clim. Dynam., 27, 727-741, doi:10.1007/s00382-0060162-4, 2006.

Clark, D. B. and Gedney, N.: Representing the effects of subgrid variability of soil moisture on runoff generation in a land surface model, J. Geophys. Res., 113, D10111, doi:10.1029/2007JD008940, 2008.

Clapp, R. B. and Hornberger, G. M.: Empirical equations for some soil hydraulic properties, Water Resour. Res., 14, 601-604, 1978.

Collins, W. J., Bellouin, N., Doutriaux-Boucher, M., Gedney, N., Hinton, T., Jones, C.D., Liddicoat, S., Martin, G., O’Connor, F., Rae, J., Senior, C., Totterdell, I., Woodward, S., Reichler, T., Kim, J., Halloran, P.: Evaluation of the HadGEM2 model. Hadley Centre Technical Note HCTN 74, Met Office Hadley Centre, Exeter, U.K.,http://www.metoffice.gov.uk/ learning/library/publications/science/climate-science, 2008.

Collins, W. J., Bellouin, N., Doutriaux-Boucher, M., Gedney, N., Halloran, P., Hinton, T., Hughes, J., Jones, C. D., Joshi, M., Liddicoat, S., Martin, G., O’Connor, F., Rae, J., Senior, C., Sitch, S., Totterdell, I., Wiltshire, A., and Woodward, S.: Development and evaluation of an Earth-system model - HadGEM2, Geosci. Model Dev. Discuss., 4, 997-1062, doi:10.5194/gmdd-4-9972011, 2011.

Cox, P. M.: Description of the TRIFFID Dynamic Global Vegetation Model. Hadley Centre Technical Note HCTN 24, Met Office, FitzRoy Road, Exeter EX1 3PB, UK, 2001.

Cox, P. M., Betts, R. A., Bunton, C. B., Essery, R., Rowntree, P. R., J. Smith, J.: The impact of new land surface physics on the GCM simulation of climate and climate sensitivity, Clim. Dynam., 15, 183-203, 1999.

Cox, P. M., Betts, R. A., Jones, C. D., Spall, S. A., and Totterdell, I. J.: Acceleration of global warming due to carbon-cycle feedbacks in a coupled climate model, Nature 408, 184-187, 2000.

Cramer W., Kicklighter, D. W., Bondeau, A., Moore III, B., Churkina, G., Nemry, B., Ruimy, A., Schloss, A. L., and The Participants of the Potsdam NPP Model Intercomparison (Bondeau, A., Churkina, G., Cramer, W., Colinet, G., Collatz, J., Dedieu, G., Emanuel, W., Esser, G., Field, C., François, L., Friend, A., Haxeltine, A., Heimann, M., Hoffstadt, J., Kaduk, J., Kergoat, L., Kicklighter, D. W., Knorr, W., Kohlmaier, G., Lurin, B., Maisongrande, P., Martin, P., McKeown, R., Meeson, B., Moore III, B., Nemani, R., Nemry, B., Olson, R., Otto, R., Parton, W., Plöchl, M., Prince, S., Randerson, J., Rasool, I., Rizzo, B., Ruimy, A., Running, S., Sahagian, D., Saugier, B., Schloss, A. L., Scurlock, J., Steffen, W., Warnant, P., and Wittenberg, U.): Comparing global models of terrestrial net primary productivity (NPP): overview and key results, Glob. Change Biol., 5, 1-15, 1999.

Curry, J. A., Schramm, J. L., Perovich, D. K., and Pinto, J. O.: Applications of SHEBA/FIRE data to evaluation of snow/ice albedo parameterizations, J. Geophys. Res., 106, 15345-15355, doi:10.1029/2000JD900311, 2001.

Derbyshire, S. H., Maidens, A. V., Milton, S. F., Stratton, R. A., and Willett, M. R.: Adaptive detrainment in a convective parametrization, Q. J. R. Meteor. Soc., doi:10.1002/qj.875, 2011.

Dharssi, I., Vidale, P., Verhoef, A., Macpherson, B., Jones, C., and Best, M.: New soil physical properties implemented in the Unified Model at PS18, Meteorology Research and Development technical report 528, Met. Office., UK, http://www.metoffice.gov.uk/learning/library/publications/ science/weather-science (last access: 18 July 2011), 2009.

Easterbrook, S. M. and Johns, T. C.: Engineering the Software for Understanding Climate Change, Comput. Sci. Eng., 11(6), 6574, doi:10.1109/MCSE.2009.193, 2009.

Edwards, J. M.: Oceanic latent heat fluxes: consistency with the atmospheric hydrological and energy cycles and general circulation modelling, J. Geophys. Res., 112, D06115, doi:10.1029/2006JD007324, 2007.

Engel, A., Möbius, T., Bönisch, H., Schmidt, U., Heinz, R., Levin, I., Atlas, E., Aoki, S., Nakazawa, T., Sugawara, S., Moore, F., Hurst, D., Elkins, J., Schauffler, S., Andrews, A., and Boering, K.: Age of stratospheric air unchanged within uncertainties over 
the past 30 years, Nat. Geosci., 2, 28-31, 2009.

Essery, R. L. H., Best, M. J., Betts, R. A., Cox, P. M., and Taylor, C. M.: Explicit representation of sub-grid heterogeneity in a GCM land-surface scheme, J. Hydrometeorol., 4, 530-543, 2003.

Falloon, P. D. and Betts, R. A.: The impact of climate change on global river flow in HadGEM1 simulations, Atmos. Sci. Lett., 7, 62-68, 2006.

Friedlingstein, P., Cox, P., Betts, R., Bopp, L., von Bloh, W., Brovkin, V., Cadule, P., Doney, S., Eby, M., Fung, I., Bala, G., John, J., Jones, C., Joos, F., Kato, T., Kawamiya, M., Knorr, W., Lindsay, K., Matthews, H.D., Raddatz, T., Rayner, P., Reick, C., Roeckner, E., Schnitzler, K.-G., Schnur, R., Strassmann, K., Weaver, A. J., Yoshikawa, C., and Zeng, N.: Climate-carbon cycle feedback analysis, results from the C4MIP model intercomparison, J. Climate, 19(14), 3337-3353 doi:10.1175/JCLI3800.1, 2006.

Gates, W. L., Boyle, J. S., Covey, C., Dease, C. G., Doutriaux, C. M., Drach, R. S., Fiorino, M., Gleckler, P. J., Hnilo, J. J, Marlais, S. M., Phillips, T. J., Potter, G. L., Santer, B. D., Sperber, K. R., Taylor, K. E., and Williams, D. N.: An overview of the results of the Atmospheric Model Intercomparison Project (AMIP I), B. Am. Meteor. Soc., 80 (1), 29-55, 1999.

Gedney. N., Cox, P. M., and Huntingford, C.: Climate feedback from wetland methane emissions, Geophys. Res. Lett., 31, L20503, doi:10.1029/2004GL020919, 2004.

Global Soil Data Task Group: Global gridded surfaces of selected soil characteristics (IGBP-DIS). Data set. available on-line from Oak Ridge National Laboratory Distributed Active Archive Center, Oak Ridge, Tennessee, U.S.A., doi:10.3334/ORNLDAAC/569, 2000.

Gregory, D. and Rowntree, P. R.: A mass flux convection scheme with representation of cloud ensemble characteristics and stability dependent closure, Mon. Weather Rev., 118, 1483-1506, 1990.

Halloran, P. R., Bell, T. G., and Totterdell, I. J.: Can we trust empirical marine DMS parameterisations within projections of future climate?, Biogeosciences, 7, 1645-1656, doi:10.5194/bg-71645-2010, 2010.

Harrison, E. F., Minnis, P., Barkstrom, B. R., Ramanathan, V., Cess, R. D., and Gibson, G. G.: Seasonal Variation of Cloud Radiative Forcing Derived from the Earth Radiation Budget Experiment, J. Geophys. Res., 95, 18687-18703, 1990.

Haywood, J. M., Osborne, S. R., Francis, P. N., Keil, A., Formenti, P., Andreae, M. O., nd Kaye, P. H.: The mean physical and optical properties of regional haze dominated by biomass burning aerosol measured from the C-130 aircraft during SAFARI 2000. J. Geophys. Res, 108(D13), 8473, doi:10.1029/2002JD002226, 2003.

Heinsch, F. A., Reeves, M., Bowker, C. F., Votava, P., Kang, S., Milesi, C., Zhao, M., Glassy, J., and Nemani, R. R.: Users Guide GPP and NPP (MOD17A2/A3) Products NASA MODIS Land Algorithm. Version 2.0. University of Montana, Missoula, MT, 2003.

Heinsch, F. A., Zhao, M., Running, S. W., Kimball, J. S., Nemani, R. R., Davis, K. J., Bolstad, P. V., Cook, B. D., Desai, A. R., Ricciuto, D. M., Law, B. E., Oechel, W. C., Kwon, H. J., Luo, H., Wofsy, S. C., Dunn, A. L., Munger, J. W., Baldocchi, D. D., Xu, L., Hollinger, D. Y., Richardson, A. D., Stoy, P. C., Siqueira, M. B. S., Monson, R. K., Burns, S. P., and Flanagan, L. B.: Evaluation of remote sensing based terrestrial productivity from MODIS using tower eddy flux network observations, IEEE T. Geosci. Remote Sens., 44, 1908-1925, doi:10.1109/TGRS.2005.853936, 2006.

Hewitt, H. T., Copsey, D., Culverwell, I. D., Harris, C. M., Hill, R. S. R., Keen, A. B., McLaren, A. J., and Hunke, E. C.: Design and implementation of the infrastructure of HadGEM3: the nextgeneration Met Office climate modelling system, Geosci. Model Dev., 4, 223-253, doi:10.5194/gmd-4-223-2011, 2011.

Hjellbrekke, A.-G.: Data Report 2000, Acidifying and eutrophying compounds, Part 2, Monthly and Seasonal Summaries, EMEP/CCC-Report 7/2002, Norwegian Institute for Air Research, 2002.

Hodges, K.: A general method for tracking analysis and its application to meteorological data, Mon. Weath. Rev., 122, 2573-2586, 1994.

Holben, B. N., Tanré, D., Smirnov, A., Eck, T.F., Slutsker, I., Abuhassan, N., Newcomb, W.W., Schafer, J.S., Chatenet, B., Lavenu, F., Kaufman, Y.J., Castle, J.V., Setzer, A., Markham, B., Clark, C., Frouin, R., Halthore, R., Karneli, A., O’Neill, N.T., Pietras, C., Pinker, R.T., Voss, K., Zibordi, G.: An emerging ground-based aerosol climatology: Aerosol optical depth from AERONET, J. Geophys. Res., 106, 9807-9826, 2001.

Houldcroft, C., Grey, W., Barnsley, M., Taylor, C., Los, S., and North, P.: New Vegetation Albedo Parameters and Global Fields of Soil Background Albedo Derived from MODIS for Use in a Climate Model, J. Hydrometeorol., 10(1), 183-198, 2009.

Hunke, E. C. and Lipscomb, W. H.: CICE: the Los Alamos sea ice model documentation and software user's manual, Version 4.0, LA-CC-06-012, Los Alamos National Laboratory, N.M., 2008.

Hurrell, J., Meehl, G. A., Bader, D., Delworth, T. L., Kirtman, B., and Wielicki, B.: A unified modeling approach to climate system prediction. B. Am. Meteor. Soc., 90, 1819-1832, doi:10.1175/2009BAMS2752.1, 2009.

Ineson, S. and Scaife, A. A.: The role of the stratosphere in the European climate response to El Niño, Nat. Geosci., 2, 32-36, doi:10.1038/ngeo381, 2008.

Inness, P. and Slingo, J. M.: Simulation of the MJO in a coupled GCM. I: Comparison with observations and an atmosphere-only GCM, J. Climate, 16, 345-364, 2003.

Jogireddy, V., Cox, P., Huntingford, C., Harding, R., and Mercado, L.: An improved description of canopy light interception for use in a GCM land-surface scheme: calibration and testing against carbon fluxes at a coniferous forest. Hadley Centre Technical Note HCTN 63, available from Met Office, FitzRoy Road, Exeter EX1 3PB, UK, http://www.metoffice.gov.uk/learning/ library/publications/science/climate-science (last access: 18 July 2011), 2006.

Johns, T. C., Durman, C. F., Banks, H. T., Roberts, M. J., McLaren, A. J., Ridley, J. K., Senior, C. A., Williams, K. D., Jones, A., Rickard, G. J., Cusack, S., Ingram, W.J., Crucifix, M., Sexton, D. M. H., Joshi, M. M., Dong, B.-W., Spencer, H., Hill, R. S. R., Gregory, J. M., Keen, A. B., Pardaens, A. K., Lowe, J. A., BodasSalcedo, A., Stark, S., and Searl, Y.: The new Hadley Centre climate model HadGEM1: Evaluation of coupled simulations, J. Climate, 19 (7), 1327-1353, 2006.

Johns, T. C., Royer, J.-F., Höschel, I., Huebener, H., Rœckner, E., Manzini, E., May, W., Dufresne, J.-L. Otterå, O. H., van Vuuren, D. P., Salas y Melia, D., Giorgetta, M. A., Denvil, 
S., Yang, S., Fogli, P. G., Körper, J., Tjiputra, J. F., Stehfest, E., and Hewitt, C. D.: Climate change under aggressive mitigation: The ENSEMBLES multi-model experiment, Clim. Dynam., doi:10.1007/s00382-011-1005-5, 2011.

Johnson, E. S., Bonjean, F., Lagerloef, G. S. E., Gunn, J. T., and Mitchum G. T.: Validation and Error Analysis of OSCAR Sea Surface Currents, J. Atmos. Ocean. Technol., 24, 688-701, 2007.

Jones, A., Roberts, D. L., Woodage, M. J., and Johnson, C. E.: Indirect sulphate aerosol forcing in a climate model with an interactive sulphur cycle, J. Geophys. Res., 106, 20293-20310, 2001.

Jones, C. D., McConnell, C., Coleman, K. W., Cox, P., Falloon, P. D., Jenkinson, D., and Powlson, D.: Global climate change and soil carbon stocks; predictions from two contrasting models for the turnover of organic carbon in soil, Global Change Biol., 11, 154-166, 2005.

Jones, C. D., Hughes, J. K., Bellouin, N., Hardiman, S. C., Jones, G. S., Knight, J., Liddicoat, S., O'Connor, F. M., Andres, R. J., Bell, C., Boo, K.-O., Bozzo, A., Butchart, N., Cadule, P., Corbin, K. D., Doutriaux-Boucher, M., Friedlingstein, P., Gornall, J., Gray, L., Halloran, P. R., Hurtt, G., Ingram, W. J., Lamarque, J.-F., Law, R. M., Meinshausen, M., Osprey, S., Palin, E. J., Parsons Chini, L., Raddatz, T., Sanderson, M. G., Sellar, A. A., Schurer, A., Valdes, P., Wood, N., Woodward, S., Yoshioka, M., and Zerroukat, M.: The HadGEM2-ES implementation of CMIP5 centennial simulations, Geosci. Model Dev., 4, 543-570, doi:10.5194/gmd-4-543-2011, 2011.

Kanzow, T., Cunningham, S. A., Johns, W. E., Hirschi, J. J.M., Marotzke, J., Baringer, M. O., Meinen, C. S., Chidichimo, M. P., Atkinson, C., Beal, L. M., Bryden, H. L., and Collins, J.: Seasonal Variability of the Atlantic Meridional Overturning Circulation at $26.5^{\circ} \mathrm{N}$, J. Climate, 23, 5678-5698, doi:10.1175/2010jcli3389.1, 2010.

Kettle, A. J., Andreae, M. O., Amouroux, D., Andreae, T. W., Bates, T. S., Berresheim, H., Bingemer, H., Boniforti, R., Curran, M. A. J., DiTullio, G. R., Helas, G., Jones, G. B., Keller, M. D., Kiene, R. P., Leck, C., Levasseur, M., Malin, G., Maspero, M., Matrai, P., McTaggart, A. R., Mihalopoulos, N., Nguyen, B. C., Novo, A., Putaud, J. P., Rapsomanikis, S., Roberts, G., Schebeske, G., Sharma, S., Simó, R., Staubes, R., Turner, S., and Uher, G.: A global database of sea surface dimethyl sulfide (DMS) measurements and a procedure to predict sea surface DMS as a function of latitude, longitude, and month, Global Biogeochem. Cy., 13(2), 399-444, 1999.

Knapp, K. R., Kruk, M. C., Levinson, D. H., Diamond, H. J., and Neumann, C. J.: The International Best Track Archive for Climate Stewardship (IBTrACS): Unifying tropical cyclone best track data, B. Am. Meteor. Soc., 91, 363-376, doi:10.1175/2009BAMS2755.1, 2010.

Lamarque, J.-F., Bond, T. C., Eyring, V., Granier, C., Heil, A., Klimont, Z., Lee, D., Liousse, C., Mieville, A., Owen, B., Schultz, M. G., Shindell, D., Smith, S. J., Stehfest, E., Van Aardenne, J., Cooper, O. R., Kainuma, M., Mahowald, N., McConnell, J. R., Naik, V., Riahi, K., and van Vuuren, D. P.: Historical (18502000) gridded anthropogenic and biomass burning emissions of reactive gases and aerosols: methodology and application, Atmos. Chem. Phys., 10, 7017-7039, doi:10.5194/acp10-7017-2010, 2010.

Large, W. G., Danabasoglu, G., McWilliams, J. C., Gent, P. R., Bryan, F. O.: Equatorial Circulation of a Global Ocean Cli- mate Model with Anisotropic Horizontal Viscosity, J. Phys. Oceanogr., 31, 2, 518-536, 2001.

Laxon, S., Peacock, N., and Smith, D.: High interannual variability of sea ice thickness in the Arctic region, Nature, 425, 947-950, doi:10.1038/nature02050, 2003.

Levitus, S., Boyer, T. P., Conkright, M. E., Orian, T., Antonov, J., Stephens, C., Stathoplos, L., Johnson, D., and Gelfeld, R.: World Ocean Database 1998, 18, NOAA Atlas NESDIS, US Department of Commerce, 1998.

Logan, J. A.: An analysis of ozonesonde data for the troposphere: Recommendations for testing 3-D models, and development of a gridded climatology for tropospheric ozone, J. Geophys. Res., 104, 16115-16149, 1999.

Madec, G.: NEMO ocean engine, Note du Pole de modèlisation, Institut Pierre-Simon Laplace (IPSL), France, No. 27, ISSN No. 1288-1619, 2008.

Malm, W. C., Sisler, J. F., Huffman, Eldred, D. R. A., and Cahill, T. A.: Spatial and seasonal trends in particle concentration and optical extinction in the United States, J. Geophys. Res., 99, 13471370, 1994.

Marquardt, C. and Naujokat, B.: An update of the equatorial QBO and its variability. 1st S PARC Gen. Assemb., Melbourne Australia, WMO/TD-No. 814, 1, 87-90, 1997.

Marshall, A. and Scaife, A. A.: Impact of the Quasi-Biennial Oscillation on Seasonal Forecasts, J. Geophys. Res., 114, D18110, doi:10.1029/2009JD011737, 2009.

Marshall, A. and Scaife, A. A.: Improved predictability of stratospheric sudden warming events in an AGCM with enhanced stratospheric resolution, J. Geophys. Res., 115, D16114, doi:10.1029/2009JD012643, 2010.

Martin, G. M., Ringer, M. A., Pope, V. D., Jones, A., Dearden, C., and Hinton, T. J.: The physical properties of the atmosphere in the new Hadley Centre Global Environment Model, HadGEM1. Part I: Model description and global climatology, J. Climate, 19, 1274-1301, 2006

Martin, G. M., Milton, S. F., Senior, C. A., Brooks, M. E., Ineson, S., Reichler, T., and Kim, J.: Analysis and Reduction of Systematic Errors through a Seamless Approach to Modelling Weather and Climate, J. Climate, 23, 5933-5957, doi:10.1175/2010JCLI3541.1, 2010.

McInturff, R. M.: Stratospheric warmings: Synoptic, dynamic and general-circulation aspects, NASA Ref. Publ. 1017, 166 pp. 1978.

McLaren, A. J., Banks, H. T., Durman, C. F., Gregory, J. M., Johns, T. C., Keen, A. B., Ridley, J. K., Roberts, M. J., Lipscomb, W., Connolley, W., and Laxon, S.: Evaluation of the Sea Ice Simulation in a new Atmosphere-Ocean Coupled Climate Model (HadGEM1), J. Geophys. Res. Oceans, 111, C12014, doi:10.1029/2005JC003033, 2006.

Menary, M., Halloran, P., Roberts, C., Jackson, L., Palmer, M. D., Wood, R. A.: The Atlantic Overturning Circulation: Building towards at fall?, in review, Nature, 2011.

Moum, J. N. and Osbourne, T. R.: Mixing in the main thermocline, J. Phys. Oceanogr., 16, 1250-1259, 1986.

Mueller, S. F.: Seasonal Aerosol Sulfate Trends for selected regions of the United States, J. Air Waste Manag., 53, 168-184, 2003.

Murphy, J. M., Sexton, D. M. H., Barnett, D. N., Jones, G. S., Webb, M. J., Collins, and Stainforth, D. A.: Quantification of modelling uncertainties in a large ensemble of climate change simulations, 
Nature, 429, 768-772, 2004.

New, M., Hulme, M., and Jones, P.: Representing twentieth century space-time climate variability. Part I: Development of a 1961-90 mean monthly terrestrial climatology, J. Climate, 12, 829-856, 1999.

O'Connor, F. M., Johnson, C. E., Morgenstern, O., and Collins, W. J.: Interactions between tropospheric chemistry and climate model temperature and humidity biases, Geophys. Res. Lett., 36, L16801, doi:10.1029/2009GL039152, 2009.

O’Connor, F. M., Johnson, C. E., Morgenstern, O., Abraham, N. L., Sanderson, M. G., Telford, P. J., Young, P. J., Zeng, G., Collins, W. J., and Pyle, J. A.: Evaluation of the new UKCA climate-composition model. Part II. The Troposphere, in preparation, Geosci. Model Develop., 2011.

Ohmura, A., Gilgen, H., Hegner, H., Müller, G., Wild, M., Dutton, E.G., Forgan, B., Fröhlich, C., Philipona, R., Heimo, A., König-Langlo, G., McArthur, B., Pinker, R., Whitlock, C.H., Dehne, K.: Baseline surface radiation network, a new precision radiometry for climate research, B. Am. Meteorol. Soc., 79, 2115-2136, doi:10.1175/15200477(1998)079<2115:BSRNBW>2.0.CO;2, 1998.

Palmer, J. R. and Totterdell, I. J.: Production and export in a global ocean ecosystem model, Deep Sea Res., Pt. I, 48, 1169-1198, doi:10.1016/S0967-0637(00)00080-7, 2001.

Perovich, D. K., Grenfell, T. C., Light, B., and Hobbs, P. V.: Seasonal evolution of the albedo of multiyear Arctic sea ice, J. Geophys. Res., 107(C10), 8044, doi:10.1029/2000JC000438, 2002.

Rae, J. G. L.: Sulphate aerosol in a climate model: effect of using on-line oxidants, M.Sc. Dissertation, University of Reading, Shinfield, Reading, 91 pp., 2008.

Randel, W. J. and Wu, F.: A stratospheric ozone profile data set for 1979-2005: Variability, trends, and comparisons with column ozone data, J. Geophys. Res., 112, D06313, doi:10.1029/2006JD007339, 2007.

Rayner, N. A., Parker, D. E., Horton, E. B., Folland, C. K., Alexander, L. V., Rowell, D. P., Kent, E. C., and Kaplan, A.: Global analysis of sea surface temperature, sea ice, and night marine air temperature since the late nineteenth century, J. Geophys. Res., 108, D14, 4407, doi:10.1029/2002JD002670, 2003.

Reichler, T. and Kim, J.: How well do coupled models simulate today's climate?, B. Am. Meteor. Soc., 89 (3), 303-311, doi:10.1175/BAMS-89-3-303, 2008a.

Reichler, T. and Kim, J.: Uncertainties in the climate mean state of global observations, reanalyses, and the GFDL climate model, J. Geophys. Res., doi:10.1029/2007JD009278, 2008b.

Ringer, M. A., Martin, G. M., Greeves, C. Z., Hinton, T. J., James, P. M., Pope, V. D., Scaife, A. A., Stratton, R. A., Inness, P. M., Slingo, J. M., and Yang G.-Y.: The physical properties of the atmosphere in the new Hadley Centre Global Environmental Model (HadGEM1). Part II: Aspects of variability and regional climate, J. Climate, 19(7), 1302-1326, 2006.

Roberts, C. D. and Palmer, M. D.: Detectability of changes to the Atlantic Meridional Overturning Circulation in the Hadley Centre Climate Models, Clim. Dynam., in preparation, 2011.

Roberts, M. J., Clayton, A., Demory, M.-E., Donners, J., Vidale, P.L., Norton, W., Shaffrey, L., Stevens, D. P., Stevens, I., Wood, R. A., and Slingo, J.: Impact of Resolution on the Tropical Pacific Circulation in a Matrix of Coupled Models, J. Climate, 22, 2541-2556, doi:10.1175/2008JCLI2537.1, 2009.
Rothrock, D. A., Percival, D. B., and Wensnahan, M.: The decline of arctic sea-ice thickness: Separating the spatial, annual, and interannual variability in a quarter century of submarine data, J. Geophys. Res., 113, C05003, doi:10.1029/2007JC004252, 2008.

Scaife, A. A., Butchart, N., Warner, C. D., Stainforth, D., Norton, W., and Austin, J.: Realistic Quasi-Biennial Oscillations in a simulation of the global climate, Geophys. Res. Lett., 27 (1), 3481-3484, 2000.

Scaife, A. A., Butchart, N., Warner, C. D., and Swinbank, R.: Impact of a spectral gravity wave parametrization on the stratosphere in the Met Office Unified Model, J. Atmos. Sci., 59, 1473-1489, 2002.

Scaife, A. A., Knight, J. R., Vallis, G. K., and Folland, C. K.: A stratospheric influence on the winter NAO and North Atlantic surface climate, Geophys. Res. Lett., 32, L18715, doi:10.1029/2005GL023226, 2005.

Scaife, A. A., Spangehl, T., Fereday, D., Cubasch, U., Langematz, U., Akiyoshi, H., Bekki, S., Braesicke, P., Butchart, N., Chipperfield, M., Gettelman, A., Hardiman, S., Michou, M., Rozanov, E., and Shepherd, T. G.: Climate Change Projections and Stratosphere-Troposphere Interaction, Clim. Dynam., 10.1007/s00382-011-1080-7, 2011.

Shaffrey, L. C., Stevens, I., Norton, W. A., Roberts, M. J., Vidale, P. L., Harle, J. D., Jrrar, A., Stevens, D. P. Woodage, M. J., Demory, M. E., Donners, J., Clark, D. B., Clayton, A., Cole, J. W., Wilson, S. S., Connolley, W. M., Davies, T. M., Iwi, A. M., Johns, T. C., King, J. C., New, A. L., Slingo, J. M., Slingo, A., Steenman-Clark, L., and Martin, G. M.: U.K. HiGEM: The New U.K. High-Resolution Global Environment Model-Model Description and Basic Evaluation, J. Climate, 22, 1861-1896, doi:10.1175/2008JCLI2508.1, 2009.

Simmons, A. J., Untch, A., Jakob, C., Kållberg, P., and Undén, P.: Stratospheric water vapour and tropical tropopause temperatures in ECMWF analyses and multi-year simulations, Q. J. Roy. Meteor. Soc., 125, 353-386, doi:10.1002/qj.49712555318, 1999.

Simmons, A., Uppala, S., Dee, D., and Kobayashi, S.: ERAInterim: New ECMWF reanalysis products from 1989 onwards, ECMWF Newsletter, No. 110, 25-35, available from ECMWF, Shinfield Park, Reading, and http://www.ecmwf.int/publications/ newsletters/ (last access: November 2010), 2007a.

Simmons, A., Uppala, S., and Dee, D.: Update on ERA-Interim., ECMWF Newsletter No. 111, 5. Available from ECMWF, Shinfield Park, Reading, and http://www.ecmwf.int/publications/ newsletters/ (last access: November 2010), 2007b.

Simo, R. and Dachs, J.: Global ocean emission of dimethylsulfide predicted from biogeophysical data, Global Biogeochem. Cy., 16 (4), 1078, doi:10.1029/2001GB001829, 2002.

Smith, D. M., Eade, R., Dunstone, N. J., Fereday, D., Murphy, J. M., Pohlmann, H., and Scaife, A. A.: Skilful multi-year predictions of Atlantic hurricane frequency, Nat. Geosci., 3, 846-849, doi:10.1038/NGEO1004, 2010.

Stroeve, J. C., Serreze, M. C., Holland, M. M, Kay, J. E., Malanik, J., and Barrett, A. P.: The Arctic's rapidly shrinking sea ice cover: a research synthesis, Climatic Change, doi:10.1007/s10584-0110101-1, 2011.

Takahashi, T., Sutherland, S. C., Wanninkhof, R., Sweeney, C., Feely, R. A., Chipman, D. W., Hales, B., Friederich, G., Chavez, F., Sabine, C., Watson, A., Bakker, D. C. E., Schuster, U., Metzl, N., Yoshikawa-Inoue, H., Ishii, M., Midorikawa, T., 
Nojiri, Y., Körtzingerm, A., Steinhoffm, T., Hoppema, M., Olafsson, J., Arnarson, T. S., Tilbrook, B., Johannessen, T., Olsen, A., Bellerby, R., Wong, C. S., Delille, B., Bates, N. R., and deBaar, H. J. W.: Climatological mean and decadal change in surface ocean $\mathrm{pCO}_{2}$, and net sea-air $\mathrm{CO}_{2}$ flux over the global oceans, Deep Sea Res. Pt. II, 56, 554-577, 2009.

Taylor, K. E.: Summarizing multiple aspects of model performance in a single diagram, J. Geophys. Res., 106, 7183-7192, 2001.

Totterdell, I. J. and Halloran, P. R.: Sensitivity of global and regional marine productivity to iron input in a coupled earth system model, Geosci. Model Dev., in preparation, 2011.

Untch, A. and Simmons, A. J.: Increased stratospheric resolution in the ECMWF forecasting system. ECMWF Newsletter, No. 82, European Centre for Medium-Range Weather Forecasting, Reading, UK, 2-8, available online at http: //www.ecmwf.int/publications/newsletters/pdf/82.pdf] (last access: 30 March 2011), 1999.

Uppala, S. M., KÅllberg, P. W., Simmons, A. J., Andrae, U., Bechtold, V. D. C., Fiorino, M., Gibson, J. K., Haseler, J., Hernandez, A., Kelly, G. A., Li, X., Onogi, K., Saarinen, S., Sokka, N., Allan, R. P., Andersson, E., Arpe, K., Balmaseda, M. A., Beljaars, A. C. M., Berg, L. V. D., Bidlot, J., Bormann, N., Caires, S., Chevallier, F., Dethof, A., Dragosavac, M., Fisher, M., Fuentes, M., Hagemann, S., Hólm, E., Hoskins, B. J., Isaksen, L., Janssen, P. A. E. M., Jenne, R., Mcnally, A. P., Mahfouf, J.-F., Morcrette, J.-J., Rayner, N. A., Saunders, R. W., Simon, P., Sterl, A., Trenberth, K. E., Untch, A., Vasiljevic, D., Viterbo, P., and Woollen, J.: The ERA-40 reanalysis, Q. J. Roy. Meteor. Soc., 131, 29613012, 2005.

Uppala, S., Dee, D., Kobayashi, S., Berrisford, P., and Simmons, A.: Towards a climate data assimilation system: status update of ERA-Interim. ECMWF Newsletter No. 115, 12-18, available from ECMWF, Shinfield Park, Reading, and http://www.ecmwf. int/publications/newsletters/ (last access: 30 March 2011), 2008.

Wilson, M. F. and Henderson-Sellers, A.: A global archive of land cover and soils data for use in general circulation climate models, J. Climate, 5, 119-143, 1985.
Wijffels, S.: Ocean Freshwater Transport, in: Ocean Circulation and Climate, edited by: Siedler, G., Church, J. A., and Gould, J., Academic Press, London, 475-488, 2001.

Wittenberg, A. T.: Are historical records sufficient to constrain ENSO simulations?, Geophys. Res. Lett., 36, L12702, doi:10.1029/2009GL038710, 2009.

Woodward, S.: Modelling the atmospheric life cycle and radiative impact of mineral dust in the Hadley Centre climate model, J. Geophys. Res., 106, D16, 18155-18166, 2001.

Woodward, S.: Mineral dust in HadGEM2. Hadley Centre Technical Note 87, Met Office Hadley Centre., Exeter, EX1 3PB, UK, available from http://www.metoffice.gov.uk/learning/ library/publications/science/climate-science (last access: 18 July 2011), 2011.

Worby, A. P., Geiger, C. A., Paget, M. J., Van Woert, M. L., Ackley, S. F., and DeLiberty, T. L.: Thickness distribution of Antarctic sea ice, J. Geophys. Res., 113, C05S92, doi:10.1029/2007JC004254, 2008.

Xie, P. and Arkin, P. A.: Global precipitation: A 17-year monthly analysis based on gauge observations, satellite estimates, and numerical model outputs, B. Am. Meteor. Soc., 78, 2539-2558, 1997.

Yin, X., Gruber, A., and Arkin, P.: Comparison of the GPCP and CMAP Merged Gauge-Satellite Monthly Precipitation Products for the Period 1979-2001, J. Hydrometeor., 5, 1207-1222, doi:10.1175/JHM-392.1, 2004.

Zhao, M., Heinsch, F. A., Nemani, R. R., and Running, S. W.: Improvements of the MODIS terrestrial gross and net primary production global data set, Remote Sens. Environ., 95, 164-176, 2005.

Zhao, M., Held, I. M., Lin, S.-J., and Vecchi, G. A.: Simulations of Global Hurricane Climatology, Interannual Variability, and Response to Global Warming Using a 50-km Resolution GCM, J. Climate, 22, 6653-6678, doi: 10.1175/2009JCLI3049.1, 2009.

Zhong, W. and Haigh, J. D.: An efficient and accurate correlated-k parameterization of infrared radiative transfer for tropospherestratosphere-mesosphere GCMs, Atmos. Sci. Lett., 1, 125-135, doi:10.1006/asle.2000.0022, 2000. 